\title{
Innovative agronomic practices for sustainable intensification in sub-Saharan Africa. A review
}

\author{
Shem Kuyah ${ }^{1,2}$ (1) Gudeta Weldesemayat Sileshi ${ }^{2} \cdot$ Libère Nkurunziza $^{2} \cdot$ Ngonidzashe Chirinda $^{3,4}$. \\ Pierre Celestin Ndayisaba ${ }^{1,5,6} \cdot$ Kangbéni Dimobe $^{7,8} \cdot$ Ingrid Öborn $^{2,9}$
}

Accepted: 26 January 2021 / Published online: 23 February 2021

(C) The Author(s) 2021

\begin{abstract}
Africa's need to double food production and feed the burgeoning human population, without compromising its natural resource base, has raised the momentum for sustainable agricultural intensification on the continent. Many studies describe agronomic practices that can increase productivity on existing agricultural land without damaging the environment and without increasing the agricultural carbon footprint. However, there is limited information on specific practices with the greatest potential to contribute to sustainable intensification on smallholder farms in sub-Saharan Africa, while simultaneously keeping the carbon footprint low. The objectives of this review were to (1) identify good agronomic practices with potential for contributing to sustainable intensification across sub-Saharan Africa, (2) synthesize available information on benefits and synergies from these technologies, and (3) discuss bottlenecks in their adoption in order to obtain insights that inform the formulation of supportive policies. Agroforestry, cereal-legume intercropping, conservation agriculture, doubled-up legume cropping, fertilizer microdosing, planting basins, and push-pull technology were identified as key agronomic innovations widely promoted in subSaharan Africa. We show that these innovations can build synergies and increase resource use efficiency while reducing agricultural carbon footprint. We outline the benefits, trade-offs, and limitations of these practices and discuss their potential role in strengthening food sovereignty and climate change adaptation and mitigation.
\end{abstract}

Keywords Agroforestry $\cdot$ Intercropping $\cdot$ Micro-dosing $\cdot$ Push-pull technology $\cdot$ Synergy $\cdot$ Trade-off

Shem Kuyah

kuyashem@gmail.com

Gudeta Weldesemayat Sileshi

sileshigw@gmail.com

Libère Nkurunziza

libere.nkurunziza@slu.se

Ngonidzashe Chirinda

Ngonidzashe.Chirinda@um6p.ma

Pierre Celestin Ndayisaba

pierrec.ndayisaba@gmail.com

Kangbéni Dimobe

kangbenidimobe@gmail.com

Ingrid Öborn

Ingrid.Oborn@slu.se

1 Department of Botany, Jomo Kenyatta University of Agriculture and Technology (JKUAT), P.O. Box 62000-00200, Nairobi, Kenya
2 Department of Crop Production Ecology, Swedish University of Agricultural Sciences (SLU), P.O. Box 7043, Uppsala 75007, Sweden

3 International Center for Tropical Agriculture (CIAT), A.A. 6713 Cali, Colombia

4 Agricultural Innovation and Technology Transfer (AITTC), Mohammed VI Polytechnic University (UM6P), Lot 660 Hay Moulay Rachid, 43150 Benguerir, Morocco

5 International Centre of Insect Physiology and Ecology (ICIPE), P.O. Box 30772-00100, Nairobi, Kenya

6 Land Husbandry and Integrated Soil Fertility Management Program, Rwanda Agriculture and Animal Resources Development Board, P.O. Box 5016, Huye, Rwanda

7 Laboratory of Plant Biology and Ecology, University Joseph Ki-Zerbo, UFR/SVT, 03 B.P. 7021, Ouagadougou, Burkina Faso

8 Institute of Environmental Sciences and Rural Development (ISEDR), University of Dédougou, Dédougou BP 176, Burkina Faso

9 World Agroforestry (ICRAF), P.O. Box 30677-00100, Nairobi, Kenya 


\section{Contents}

1. Introduction

2. Methods

3. Scope, search strategy, and selection of studies

3.1. Evaluation of agronomic practices

3.2 Potential agronomic practices

3.3. Cereal-legume intercropping

3.4. Doubled-up legume technology

3.5. Conservation agriculture

3.6. Agroforestry practices

3.7. Planting basins

3.8. Push-pull technology

3.9. Fertilizer and manure micro-dosing

4. Potential for reducing the carbon footprint of agriculture

5. Conclusions and recommendations

References

\section{Introduction}

Sub-Saharan Africa (SSA) is characterized by low-input agriculture that leads to low yields. To offset the yield gap, the region depends on further land clearing and deforestation (Vanlauwe et al. 2014), which has led to rapid degradation of over 95 million hectares of land in SSA (Nkonya et al. 2016). In agricultural landscapes, poor farmers open up and over-crop marginal land because they lack alternative income sources or better farming technology. In terms of total economic value, the cost of land degradation is estimated at US\$65 billion per year or about $7 \%$ of the total GDP of the SSA region (Nkonya et al. 2016). Clearing of forests for agriculture, loss of vegetative cover, and depletion of soil organic matter are recognized as the root causes of most soil degradation in SSA (FAO and ITPS 2015). Reversing these trends requires identifying new or existing agronomic innovations that can increase food production from the available land while reducing the carbon footprint from agriculture (Fig. 1). To reduce carbon footprint, land clearance rates for agricultural purposes will have to decrease and the necessary yield increases achieved through innovations on existing agricultural land. The challenge is that SSA farming is primarily based on smallholder systems where farmers produce for subsistence, with limited or no access to external inputs, or are marginalized from produce markets (AGRA 2017). While these low-input smallholder farming systems result in low greenhouse gas (GHG) emissions, they are also low-yielding.

There is growing interest in sustainable intensification, defined as producing more output from the same area of land while reducing the negative environmental impacts and, at the same time, increasing contributions to natural capital and the flow of environmental services (Pretty et al. 2011; Smith et al. 2017). Sustainable intensification is particularly crucial for $\mathrm{SSA}$, a region projected to reach a population of 2.5 billion, or $21 \%$ of the total world population, by 2050 (United Nations 2017). Besides the growing population, rapid urbanization and rising consumer purchasing power are projected to increase food demand in the region (AGRA 2017). Climate change is another challenge that requires innovative ways of farming to mitigate crop losses associated with both long-term climatic changes and extreme weather events. To meet the projected doubling of food demand, $80 \%$ of the required increase in crop production in developing countries, including SSA, must come from improved varieties and agronomic practices, with only $20 \%$ coming from expanding arable land (Bruinsma 2009). Without innovative farming practices, the $\sim 70 \%$ of the continent's population who are engaged in agriculture (AGRA 2017) will continue producing at below average world production levels, due to low soil fertility, water stress, crop pests and diseases, and climate change shocks (Calzadilla et al. 2009).

The dramatic increases in harvested area for the main food crops in SSA (Fig. 2a, c-f) show that $91-98 \%$ of the increase in maize (Zea mays L.), cassava (Manihot esculenta Crantz), beans (Phaseolus vulgaris L.), soybean (Glycine max (L.) Merr.), and pigeon pea (Cajanus cajan (L.) Huth) production have been achieved through an increase in area (FAO 2019). In comparison, only 2-8\% derive from an increase in productivity. Yet, merely bringing more land into agriculture is neither viable nor sustainable for attaining food security (Vanlauwe et al. 2014). Many factors support these propositions, underscoring the need for increased adoption of agronomic innovations in SSA. First, much of the land that is ideal for farming is already being cultivated, and the remaining land that can potentially be brought to cultivation is marginal or under conserved natural ecosystems (Vanlauwe et al. 2014). Second, bringing more land into cultivation has no benefits, since the ability to produce food in SSA is limited by the demand for land from other human activities and the need to reduce GHG emissions from land clearance (AGRA 2017). Third, climate change, land degradation, and other consequences of unsustainable land management are expected to lower crop production in the region by approximately $1.6 \%$ by 2050 if no adaptation actions are taken (Calzadilla et al. 2009). This raises the need to address factors that limit production by fully exploiting appropriate genotype, management, and environment interactions that increase crop productivity and yields.

Despite the impressive gains in crop improvement in some countries, the average yield gains for some crops have remained static (Fig. 2a-f) or have declined in many areas (Bruinsma 2009; Grassini et al. 2013; Ray et al. 2013; Abate 
Fig. 1 Examples of innovations reported to contribute to sustainable food systems in subSaharan Africa. a Cereal-legume intercropping (maize-soybean intercrop in Rwanda). b Conservation agriculture (mulched soybean). c Agroforestry (parkland trees with maize in Burkina Faso). d Pushpull technology (maize intercropped with desmodium with Napier grass as a border crop in Kenya)
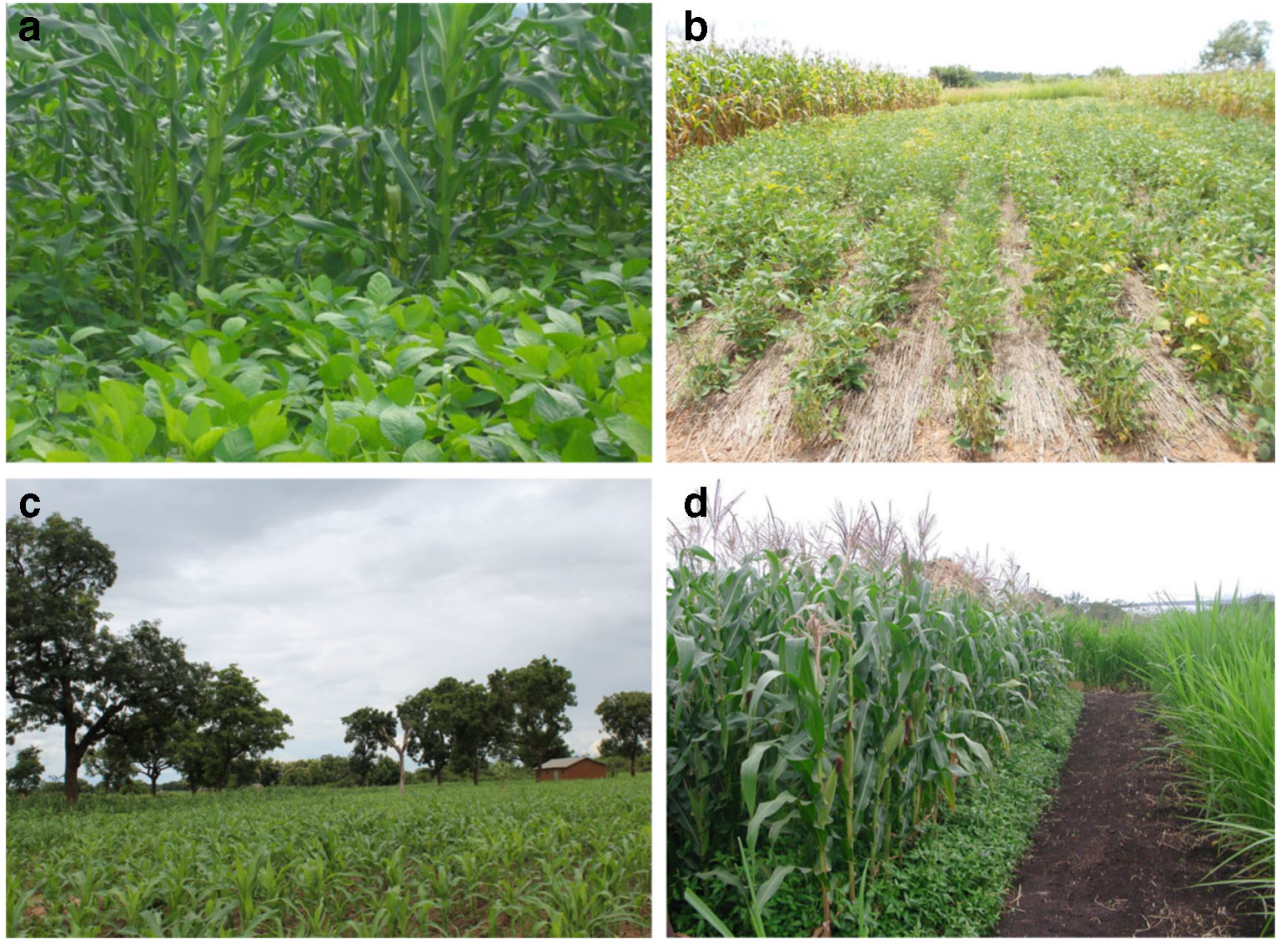

et al. 2017). For example, up to 214 improved maize varieties with yield potential $>5 \mathrm{Mg} \mathrm{ha}^{-1}$ have been released in many SSA countries since the 1960s (Abate et al. 2017) (Fig. 3). However, maize yields in SSA have remained below $2 \mathrm{Mg}$ $\mathrm{ha}^{-1}$ during the same period (Grassini et al. 2013) (Fig. 2a). These trends are particularly troubling in Kenya, Zambia, and Zimbabwe, where maize yields are decreasing by $0.2-7.6 \%$ per year (Ray et al. 2013) despite the large number of improved varieties released in these countries (Fig. 3b). Similar trends are evident for other crops despite significant crop variety improvements (Fig. 2). Improved varieties can only perform to their genetic potential when good agronomic practices (GAPs) are applied. In food-insecure regions, productivity gains from improved management are often far greater than those from improved genetics.

Good agronomic practices serve more than one purpose; they increase crop production and productivity through more efficient use of agricultural inputs while reducing emissions and losses. Benefits derived from a particular technology or management practice depend on execution and context of its application. Yet information on innovations that have the most significant potential to contribute to sustainable intensification of farming in SSA is limited. This knowledge gap has hampered formulation of evidence-based policies supporting scaling up of GAPs and, consequently, their broad adoption in the region. The objectives of this narrative review were therefore to (1) identify GAPs with the potential to contribute significantly to sustainable intensification across SSA, (2) provide a synthesis of their ability to provide multiple benefits and synergies, and (3) discuss bottlenecks in their adoption. These three objectives were intended to provide insights that can inform the formulation of supportive policies.

\section{Methods}

\subsection{Scope, search strategy, and selection of studies}

We performed a critical review of the literature to identify GAPs widely promoted as entry points for sustainable intensification of agriculture in SSA. The review process involved an online search of material indexed in bibliographic databases and other sources (Fig. 4). First, we identified a list of sustainability indicators in agricultural production, focusing on two sustainable intensification domains, productivity and environment. Among the indicators for sustainable intensification, crop yield is the most common productivity indicator (Smith et al. 2017). We focused on crop yield because increasing crop productivity is a fundamental characteristic of intensification (Musumba et al. 2017). We also included soil quality, input (nutrient, water) use efficiency, pest control, and GHG emissions as indicators of sustainable intensification. Scientific evidence shows that poor soils, input use inefficiencies, and pests are major constraints to productivity, while the continuing rise in GHG emissions is responsible for climate change, negatively impacting agricultural production.

We applied search strings with the following keywords to retrieve publications indexed in Web of Science and Scopus: TS=(("crop yield" OR "soil quality" OR "soil fertility" OR "soil moisture" OR "water use efficiency" OR "nutrient use 
Fig. 2 Comparison of trends in area harvested (million ha) and yield $\left(\mathrm{Mg} \mathrm{ha}^{-1}\right)$ of crops for which significant progress has been made in breeding in Africa (1960-2017). a Maize (Zea mays L.). b Wheat (Triticum aestivum L.). c Cassava (Manihot esculenta L.). d Common beans (Phaseolus vulgaris L.). e Soybean (Glycine $\max$ L.). f Pigeon pea (Cajanus cajan L.). All values calculated from FAOSTAT data (2019)
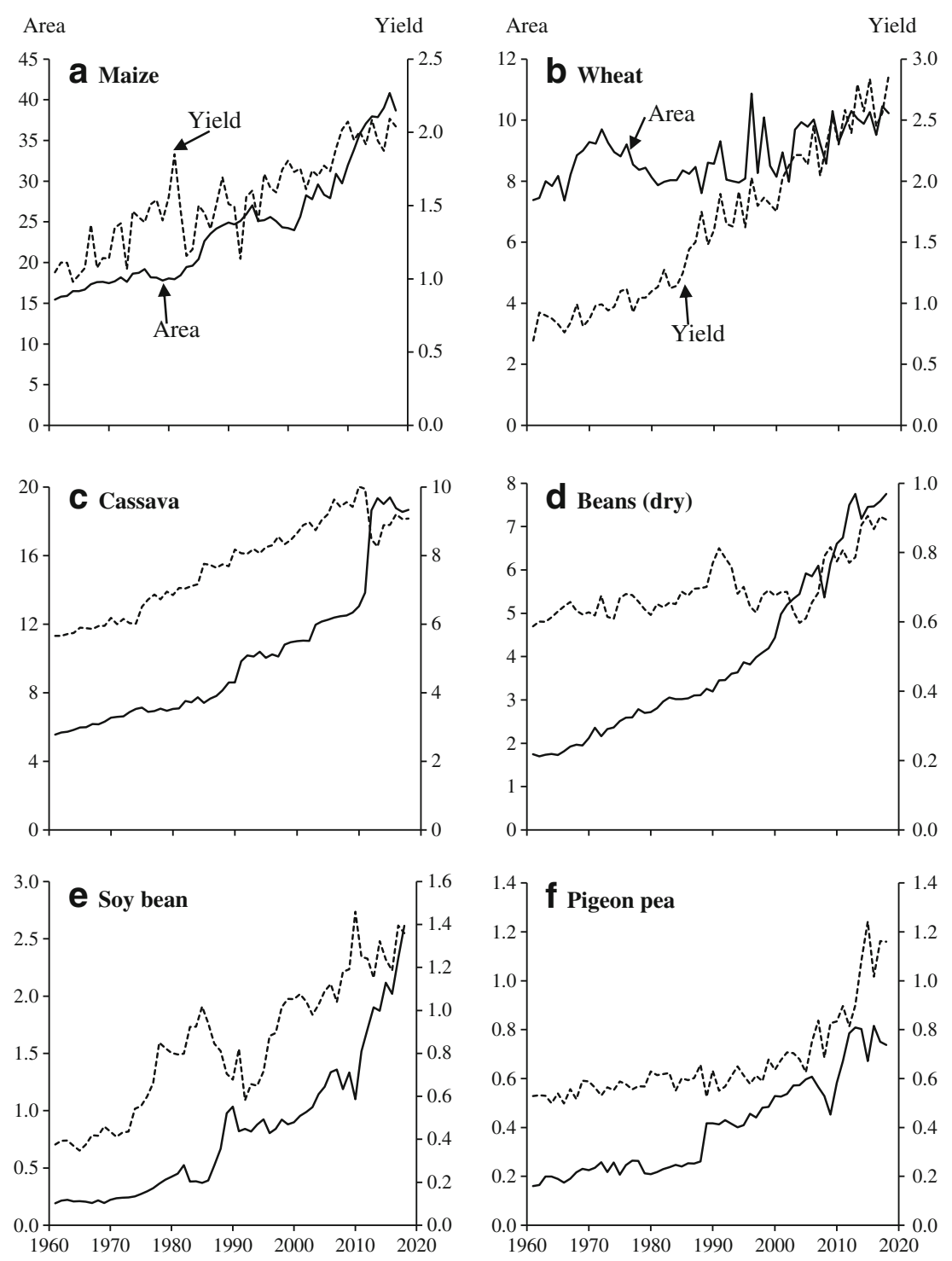

efficiency" OR "pest" OR “disease” OR "weed" OR "greenhouse gas emission") AND ("sustainable intensification") AND ("sub-Saharan Africa")). The search was conducted for publications in the English language covering the period 1997-2020. This covered the time when Pretty (1997) first coined the term "sustainable intensification" and when the literature on sustainable intensification increased (Weltin et al. 2018). We complemented electronic searches on bibliographic databases by checking references of the papers retrieved from Google Scholar searches. The search yielded a total of 577 peer-reviewed publications (Fig. 4). We assessed the relevance of publications retrieved by reviewing the title and abstract and finally conducting full-text appraisals. To be included in the synthesis, publications had to report a specific agronomic practice or a group of practices on experiments conducted in SSA and the corresponding impact on the indicators identified in Table 1.

\subsection{Evaluation of agronomic practices}

From 87 publications meeting the selection criteria, we identified seven agronomic practices that improve either one or a combination of factors contributing to sustainable intensification of crop production systems. Whenever available, information on the land area covered by the agronomic practices or the number of farmers that use the practices was retrieved. A vote-count approach was used to determine the impact of agronomic practices on five major factors (crop yield, soil quality, input use efficiency, pest control, GHG emissions) contributing to sustainable intensification of agricultural production systems. Each study was categorised as having a positive, negative or neutral effect. A positive effect suggests an increase or improvement in a given indicator, a negative effect suggests a decrease, and a neutral outcome suggests no significant effect or a context-specific effect. Reductions in GHG 
Fig. 3 Number of maize varieties released between 1960 and 2013 in various countries. a Variation by year. b Variation by country

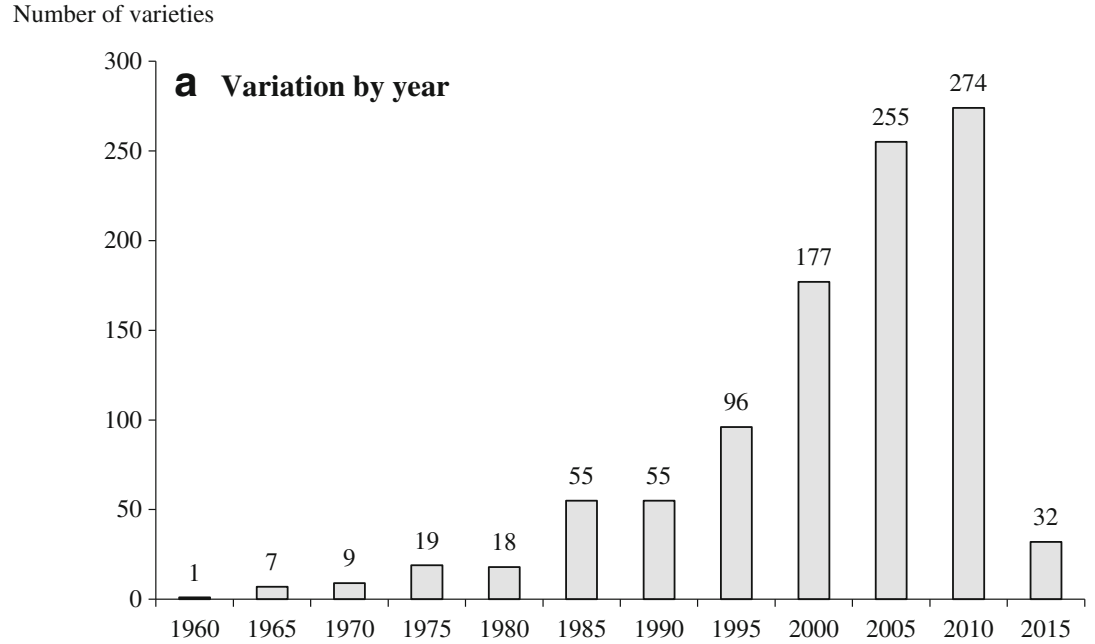

Number of varieties

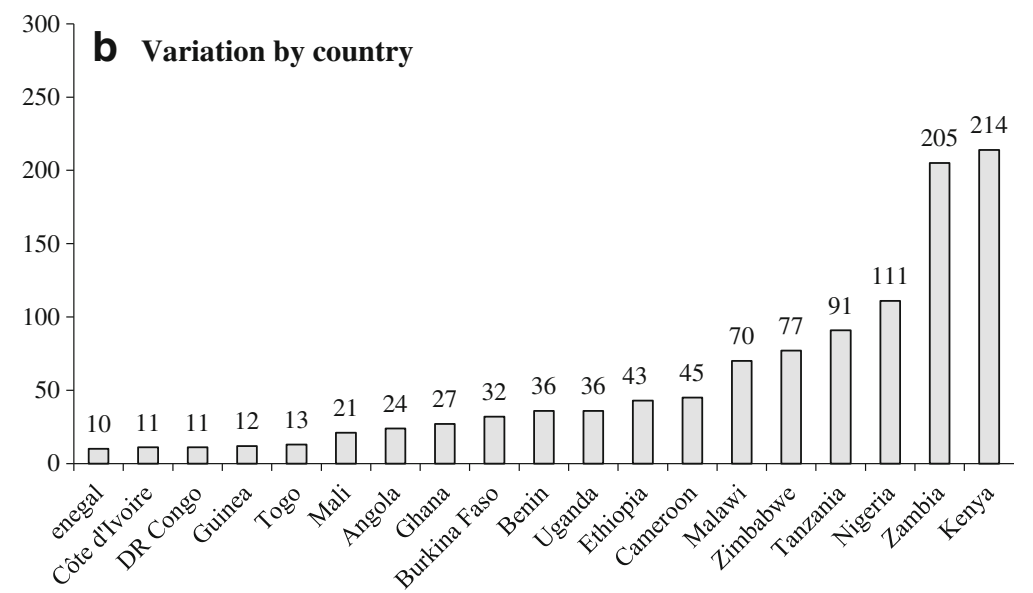

emissions were considered a positive effect. Results from vote counts were augmented by an expert knowledge-based assessment of the importance of agronomic practices identified for sustainable intensification. The assessment used the advantages and limitations reported to assign positive and/or negative contributions to sustainable intensification.
We obtained total emission data for the various sectors, i.e., energy, agriculture, industrial processes, and products and waste, from FAOSTAT for the period 1997-2017 (FAO 2019), to calculate the contribution of agriculture to total GHG emissions (Fig. 5). The total GHG emission data provide a complete picture of the contribution of agriculture to
Fig. 4 Comparison of trends in emissions from agriculture with other sectors. a Amount in carbon dioxide $\left(\mathrm{CO}_{2}\right)$ equivalents. b Percentage contribution of each sector to total emissions. All values calculated from FAOSTAT data (2019) using the IPCC fifth assessment report (IPCC 2014). Solid lines represent actual values 1990 2017, while broken lines are forecast values for 2050

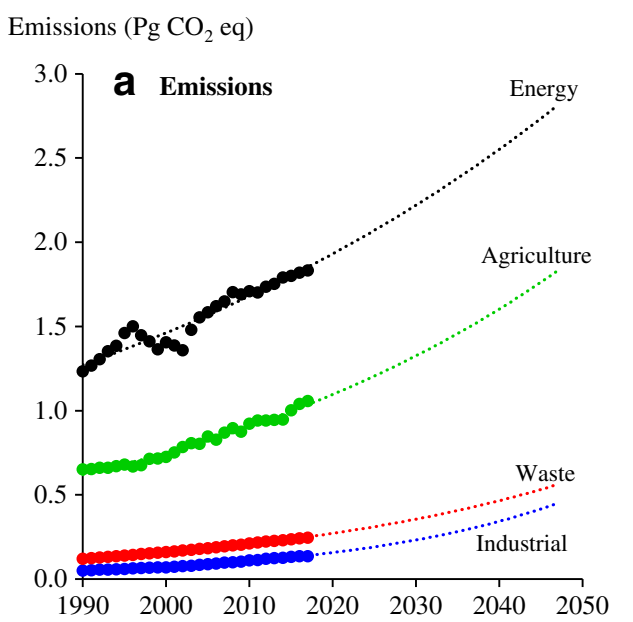

Contribution $(\%)$

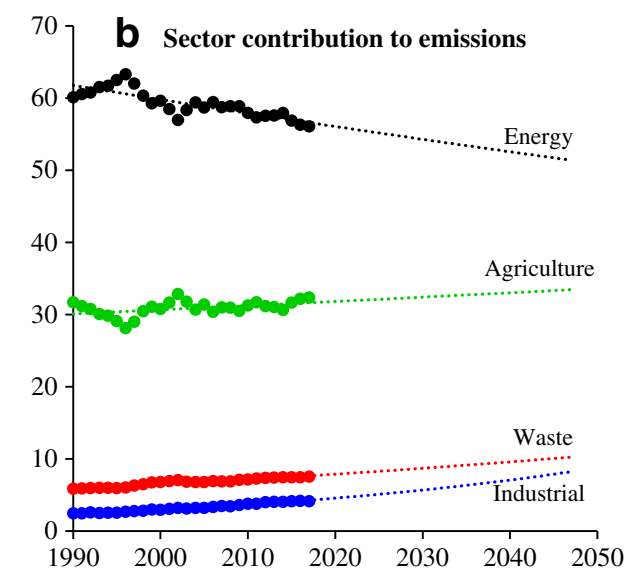


Table 1 Estimated area (in million hectares) under the various interventions or estimated number of farmers practicing the interventions and their impacts on crop yields, soil quality, input use efficiency, pest control, and greenhouse gas emissions. The values indicate the number of studies reporting an impact of the practice on the indicators. $+/-$ means that the practice had a neutral impact or the impact was context-specific according to the study

\begin{tabular}{|c|c|c|c|c|c|}
\hline \multirow{2}{*}{$\begin{array}{l}\text { Agronomic } \\
\text { practice }\end{array}$} & \multirow{2}{*}{$\begin{array}{l}\text { Approximate } \\
\text { area/number } \\
\text { of farmers }\end{array}$} & Indicator & & & \multirow[t]{2}{*}{ References } \\
\hline & & $\begin{array}{ll}\text { Crop } & \text { Soil } \\
\text { yield } & \text { quality }\end{array}$ & $\begin{array}{ll}\text { Input use } & \text { Pest } \\
\text { efficiency } & \text { control }\end{array}$ & $\begin{array}{l}\text { GHG } \\
\text { emissions }\end{array}$ & \\
\hline
\end{tabular}

\begin{tabular}{cccccccc}
\hline Cereal-legume & \multirow{2}{*}{ NA } & Increase (+) & 18 & 3 & 3 & 2 & 1 \\
intercropping & & Neutral (+/-) & 6 & 1 & & & \\
& & Decrease (-) & 2 & & & &
\end{tabular}

(Drinkwater et al. 1998; Rao and Mathuva 2000;

Snapp et al. 2002a, p. 2002b, p. 2018a, p. 2018b; Myaka et al. 2006; Waddington et al. 2007; Kimaro et al. 2009; Rusinamhodzi et al. 2012, 2020; Ojiem et al. 2014; Arslan et al. 2015; Falconnier et al. 2016; Droppelmann et al. 2017; Franke et al. 2018; van Vugt et al. 2018; Chimonyo et al. 2019; Demissie et al. 2019; Kermah et al. 2019; Kiwia et al. 2019; Diatta et al. 2020; Madembo et al. 2020; Namatsheve et al. 2020; Nassary et al. 2020a, b; Mupangwa et al. 2021)

\begin{tabular}{|c|c|c|c|c|c|c|}
\hline $\begin{array}{l}\text { Doubled-up } \\
\text { legume } \\
\text { technology }\end{array}$ & & $\begin{array}{l}\text { Increase }(+) \\
\text { Neutral }(+/-) \\
\text { Decrease (-) }\end{array}$ & 5 & $\begin{array}{l}3 \\
1\end{array}$ & & \\
\hline $\begin{array}{l}\text { Conservation } \\
\text { agriculture (CA) }\end{array}$ & $7.7^{*}$ & $\begin{array}{l}\text { Increase }(+) \\
\text { Neutral }(+/-) \\
\text { Decrease }(-)\end{array}$ & $\begin{array}{l}17 \\
8 \\
1\end{array}$ & $\begin{array}{l}6 \\
2\end{array}$ & 6 & 1 \\
\hline
\end{tabular}

(Snapp et al. 2002a, p. 2002b, p. 2002; Chikowo et al. 2015, 2020; Smith et al. 2016)

(Rusinamhodzi et al. 2011, 2012; Bayala et al. 2012; Arslan et al. 2015; Nyagumbo et al. 2015, 2016, 2020; Pittelkow et al. 2015a, b; TerAvest et al. 2015; Thierfelder et al. 2015, 2016, 2017; Micheni et al. 2016; Mupangwa et al. 2016, 2018, 2019, 2021; Droppelmann et al. 2017; Kafesu et al. 2018; Magombeyi et al. 2018; Mashavakure et al. 2018; Assefa et al. 2019; Belay et al. 2019; Corbeels et al. 2019; Komarek et al. 2019; Kihara et al. 2020; Mutuku et al. 2020; Yimam et al. 2020)

\begin{tabular}{|c|c|c|c|c|c|c|c|}
\hline $\begin{array}{l}\text { Agroforestry and } \\
\text { cover cropping }\end{array}$ & $113.8^{\dagger}$ & $\begin{array}{l}\text { Increase }(+) \\
\text { Neutral }(+/-) \\
\text { Decrease }(-)\end{array}$ & $\begin{array}{l}4 \\
3 \\
3\end{array}$ & $\begin{array}{l}7 \\
2\end{array}$ & $\begin{array}{l}4 \\
2\end{array}$ & 2 & $\begin{array}{l}\text { (Kinama et al. 2007; Mutegi et al. 2008; Sileshi et al. } \\
\text { 2008; Baudron et al. 2015; Pumariño et al. 2015; } \\
\text { Kuyah et al. 2016, 2019; Droppelmann et al. } \\
\text { 2017; Blaser et al. 2018; Magombeyi et al. 2018; } \\
\text { Rahn et al. 2018; Sida et al. 2018, 2020; Wolka } \\
\text { et al. 2018; Kuria et al. 2019; Muchane et al. } \\
\text { 2020) }\end{array}$ \\
\hline Planting pits & & $\begin{array}{l}\text { Increase }(+) \\
\text { Neutral }(+/-) \\
\text { Decrease }(-)\end{array}$ & 10 & 5 & $\begin{array}{l}5 \\
1\end{array}$ & 2 & $\begin{array}{l}\text { (Roose et al. 1999; Malley et al. 2004; Fatondji et al. } \\
\text { 2006; Amede et al. 2011; Zougmoré et al. 2014; } \\
\text { Thierfelder et al. 2015; Kafesu et al. 2018; } \\
\text { Magombeyi et al. 2018; Mashavakure et al. 2018; } \\
\text { Dahlin and Rusinamhodzi 2019; Chilagane et al. } \\
\text { 2020; Ibrahim and Fatondji 2020; Muchai et al. } \\
\text { 2020) }\end{array}$ \\
\hline Push-pull & $70,000^{*}$ & $\begin{array}{l}\text { Increase }(+) \\
\text { Neutral }(+/-) \\
\text { Decrease }(-)\end{array}$ & 10 & & & 10 & $\begin{array}{l}\text { (Khan et al. 2002, 2006, 2009, 2014; Midega et al. } \\
\text { 2015, 2017, 2018; Kebede et al. 2018; D'Annolfo } \\
\text { et al. 2020; Ndayisaba et al. 2020) }\end{array}$ \\
\hline $\begin{array}{l}\text { Fertilizer and } \\
\text { manure } \\
\text { micro-dosing }\end{array}$ & & $\begin{array}{l}\text { Increase }(+) \\
\text { Neutral }(+/-) \\
\text { Decrease }(-)\end{array}$ & 22 & $\begin{array}{l}2 \\
1 \\
2\end{array}$ & & & $\begin{array}{l}\text { (Aune et al. 2007; Ncube et al. 2007; Tabo et al. } \\
\text { 2007; Hayashi et al. 2008; Twomlow et al. 2010; } \\
\text { Bielders and Gérard 2015; Ibrahim et al. 2015, } \\
\text { 2016a, b; Adams et al. 2016; Okebalama et al. } \\
\text { 2016; Tonitto and Ricker-Gilbert 2016; } \\
\text { Tovihoudji et al. 2017, 2019; Vandamme et al. } \\
\text { 2018; Coulibaly et al. 2019; De Bauw et al. 2019; } \\
\text { Saidia et al. 2019; Nourou et al. 2020; Ouedraogo } \\
\text { et al. 2020) }\end{array}$ \\
\hline
\end{tabular}

* Conservation agriculture is estimated to be below $1 \%$ of agricultural land in sub-Saharan Africa

${ }^{\dagger}$ Area of agricultural land with greater than $10 \%$ tree cover $\left(1,137,864 \mathrm{~km}^{2}\right)$ in 2010 (Zomer et al. 2014)

${ }^{\star}$ Number of farmers that have adopted the push-pull technology. As of 2014, an estimated 68,800 smallholder farmers in Kenya, Uganda, Tanzani, and Ethiopia had adopted push-pull technology (Khan et al. 2014) 
atmospheric carbon dioxide $\left(\mathrm{CO}_{2}\right)$, methane $\left(\mathrm{CH}_{4}\right)$, and nitrous oxide $\left(\mathrm{N}_{2} \mathrm{O}\right)$ concentrations, which are associated with crop and livestock production and related management activities (FAO 2019). We summarised values computed using the IPCC fifth assessment report (IPCC 2014) and expressed them in $\mathrm{Pg}\left(10^{15} \mathrm{~g}\right)$ carbon dioxide equivalents $\left(\mathrm{CO}_{2}\right.$ eq. $)$. We also obtained data from FAOSTAT for the period 1997-2017 (FAO 2019) to show trends in the harvested area and yield of maize, wheat (Triticum aestivum L.), cassava, common bean, soybean, and pigeon pea. These were selected because they are the main crops that have received significant investments for breeding and agronomic research in SSA.

\section{Potential agronomic practices}

We identified seven agronomic practices that can potentially contribute, or are already contributing, to sustainable intensification in SSA (Table 1). In terms of land area or the number of farmers that use the practices, information was only available for four of the seven practices. The other three practices showed lower importance at the regional scale. All the practices showed several positive impacts on sustainable intensification indicators, with a few negative impacts. Below, we provide detailed reviews of the seven agronomic practices and discuss the reasons for their adoption or non-adoption by smallholder farmers.

\subsection{Cereal-legume intercropping}

Intercropping cereals with legumes is an old tradition that has been practised by most smallholder farmers throughout much of SSA and has been identified as one of the sustainable intensification strategies in smallholder agriculture in SSA (Snapp et al. 2002b, 2018b; Kiwia et al. 2019). A review of the potential role of cereal-legume intercropping systems in integrated soil fertility management in smallholder farming systems of SSA has been carried out previously (Kiwia et al. 2019). However, accurate estimates of the area under intercropping are still not available. Typically, cereals constitute the main crop. Common cereals in SSA include maize, sorghum (Sorghum bicolor L. Moench.), and finger millet (Eleusine coracana L. Gaertn.). Legumes are generally the companion crop and can be selected to produce food, e.g., pigeon pea, cowpea (Vigna unguiculata L. Walp.), common bean or groundnut (Arachis hypogea L.), and/or fodder, e.g., Stylosanthes spp., Trifolium spp., and Vicia spp. Cereallegume intercropping is common in Southern and East Africa, where maize is traditionally intercropped with common bean, pigeon pea, cowpea, or soybean. Compared with sole cropping (monocultures), cereal-legume intercropping increased crop yield in 18 of the studies reviewed $(n=87)$, reduced yield in six studies, and did not have a significant effect in two studies (Table 1). In most studies, the increased yield was attributed to improved soil fertility through biological nitrogen fixation. Under certain situations, intercropping
Fig. 5 Flow diagram of the review process showing the number of studies returned by the search and studies included or excluded at each stage

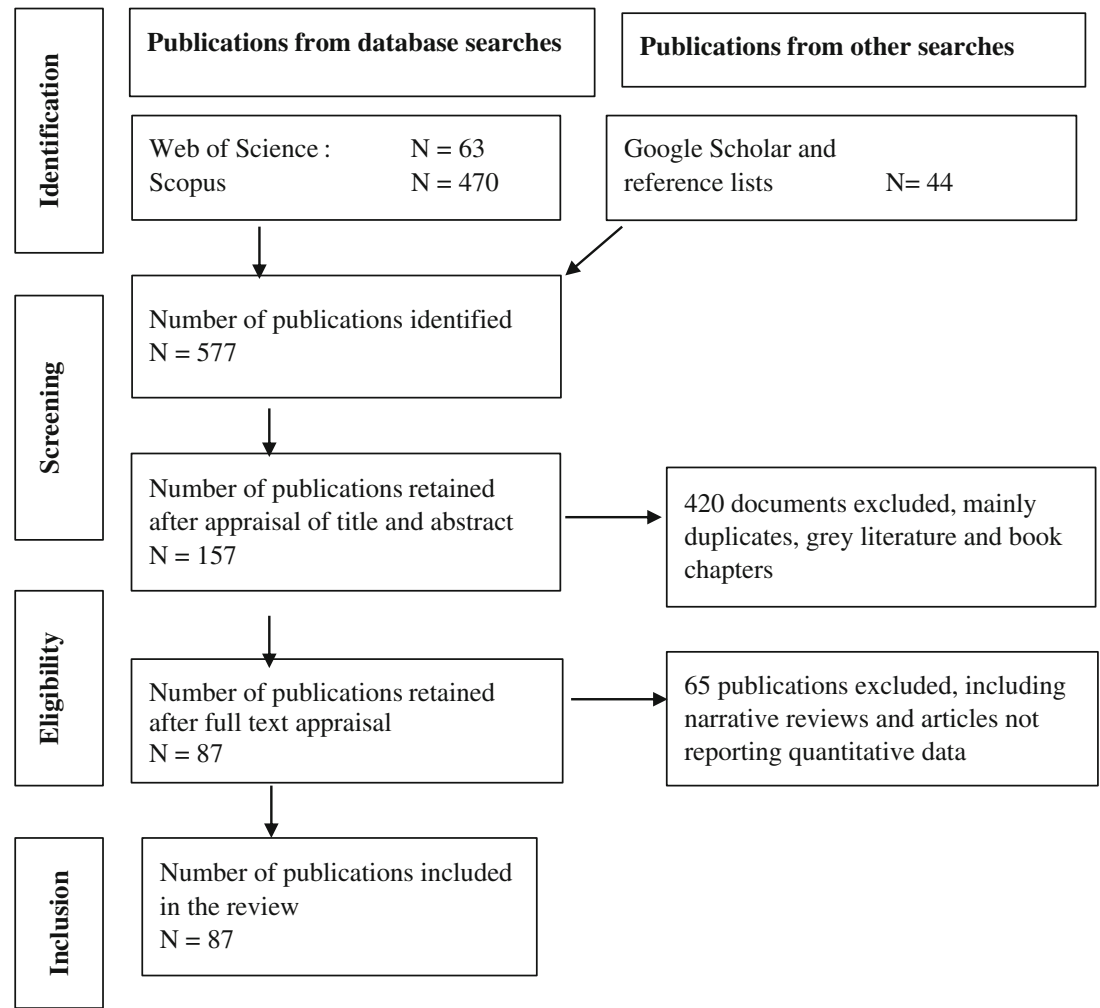


contributed to reducing yield losses by controlling weeds or regulating pest or disease populations (Rusinamhodzi et al. 2012; Franke et al. 2018). Studies reporting effects of intercropping on soil quality, improved input use efficiency, pest control, and GHG emissions were few (Table 1).

Pigeon pea is one of the legumes shown to have high potential for intercropping with cereals in Southern and East Africa, where it plays a vital role in household nutrition and income generation (Snapp et al. 2002a; Kiwia et al. 2019). Unlike most legumes, pigeon pea is well adapted to semiarid and arid regions, where it is grown in association with maize, sorghum or millet (Odeny 2007). Growing pigeon pea as an intercrop with cereals diversifies the production system and reduces risks associated with monocultures, such as high use of fertilizers, high pest pressure, loss of biodiversity, degradation of soil quality, and environmental pollution (Snapp et al. 2010; Kiwia et al. 2019). In Burkina Faso, Malawi, and Mozambique, growing maize with pigeon pea has been found to reduce crop failure risk even when fertilizer is not applied (Snapp et al. 2010; Rusinamhodzi et al. 2012; Kiwia et al. 2019). Pigeon pea harvested during the dry season has been found to represent a food source that helps bridge hunger periods in Tanzania and Malawi (Myaka et al. 2006; Kimaro et al. 2009).

Intercropping pigeon pea with maize has been shown to produce higher yields per unit area. Maize intercropped with pigeon pea can achieve yields comparable with, or higher than, those obtained in sole maize cropping (Rao and Mathuva 2000; Myaka et al. 2006) due to increased soil fertility over time (Snapp et al. 2002b; Rusinamhodzi et al. 2012; Kiwia et al. 2019). In semi-arid Kenya (the Machakos area), maize-pigeon pea intercropping produced $24 \%$ higher maize yields $\left(2.67 \mathrm{Mg} \mathrm{ha}^{-1}\right)$ than the mono-cropped maize $(2.46 \mathrm{Mg}$ $\mathrm{ha}^{-1}$ ) (Rao and Mathuva 2000). In Tanzania, the yield of unfertilized maize intercropped with pigeon pea was similar to the yield of a moderately fertilized maize crop (Myaka et al. 2006). Across Malawi, the average grain yield of maize and pigeon pea over two years in on-farm trials was higher than in monoculture systems (Snapp et al. 2002b). Farmers who grow pigeon pea can also benefit from fodder for livestock and firewood for household energy needs.

The primary trade-off in cereal-legume intercropping is competition for growth factors that negatively affect crop yield (Waddington et al. 2007; Kimaro et al. 2009; Kiwia et al. 2019). Legumes also face competition for land, labor, and cash with other crops and farm activities (Snapp et al. 2002b). In Tanzania, intercropping maize-pigeon pea was found to enhance maize yield over sole maize only when fertilized, suggesting possible competition for nutrients (Kimaro et al. 2009). In a long-term experiment in northcentral Zimbabwe, Waddington et al. (2007) found that maize was suppressed when intercropped with pigeon pea during some growing seasons. Some legumes contribute small amounts of nitrogen to the next crop, since large amounts of the nitrogen fixed by the legume are removed when the grain and residues are harvested and removed from the field. However, longer season legumes (e.g., pigeon pea) can increase the amount of fixed nitrogen. Where intercropping is likely to suppress yields or increase nutrient mining, applying the recommended doses of nitrogen and phosphorus fertilizers or manure has been demonstrated to increase yields and net incomes (Kiwia et al. 2019).

\subsection{Doubled-up legume technology}

Doubled-up legume technology involves intercropping two legumes with complementary growth habits and plant architecture in rotation with a cereal (Chikowo et al. 2015; Smith et al. 2016). Smallholder farmers widely use this practice in Malawi, where mixtures of pigeon pea and soybean or groundnut or cowpea are grown (Rogé et al. 2016; Smith et al. 2016). The practice takes advantage of synergies that occur when crops in the mixtures place significant demands on resources at different times or exploit resources at different depths within the soil profile. In principle, the two legumes are planted as they would be in a sole crop. When pigeon pea and groundnuts are planted simultaneously, the pigeon pea plants grow slowly for the first two months, allowing groundnut plants to grow with little competition for water, nutrients, and sunlight (Chikowo et al. 2015, 2020). Pigeon pea then starts growing fast when the groundnut is approaching maturity and continues to grow as a sole crop until it is harvested (Chikowo et al. 2015, 2020).

Doubled-up legumes offer multiple benefits in cropping systems compared with monoculture practices (Snapp et al. 2010; Chikowo et al. 2020). Five of the studies reviewed indicated that doubled legume technology increases crop yield. Under good rainfall, the technology raises land productivity, allowing farmers to benefit from two-grain harvests. Evidence of greater yields from legume-legume systems is documented for countrywide trials conducted in Malawi. Across different environments, sole groundnut and pigeon pea produced 1.4 and $0.9 \mathrm{Mg} \mathrm{ha}^{-1}$, respectively, compared with 1.2 and $0.5 \mathrm{Mg} \mathrm{ha}^{-1}$ in the doubled-up system (Chikowo et al. 2015). These yield levels suggest that pigeon pea intercropped with groundnut can produce yields close to sole-cropped pigeon pea. Doubled-up legumes also increased the yield of maize grown in the subsequent seasons. After 2 years of pigeon pea/groundnut intercrop, maize yield increased by $45 \%$ across various Malawian environments (Snapp et al. 2002a, b). Using data from 26 growing seasons, Smith et al. (2016) found that maize grain yields in doubledup legume rotations and maize-legume rotations were comparable and surpassed yields in a maize/pigeon pea intercrop and sole-cropped maize where similar fertilizer inputs were applied. Yields of maize grown after the intercrop were higher 
than yields in conventional cereal-legume intercropping (Smith et al. 2016). Trials in eastern Zambia also showed the potential of doubled-up legumes, with better spatial arrangement of groundnut in pigeon pea recommended for increasing the yield of maize planted after the legumes (Thierfelder et al. 2017).

Doubled-up legumes have been shown to improve soil fertility, as both crops contribute above and below biomass and fix nitrogen through biological fixation (Smith et al. 2016). Improved soil fertility results from large amounts of organic mulch from pigeon pea leaves that fall to the ground as the crop matures. Residues produced by legume-based systems in on-farm trials in Malawi contained about $50 \mathrm{~kg} \mathrm{~N}^{-1}$ year $^{-1}$, twice the amount of residues from sole-cropped maize (Snapp et al. 2002b). As the other legume (soybean or groundnuts) intercropped with pigeon peas also fixes nitrogen, the doubled-up legume intercropping system results in 20-50\% more biological nitrogen fixation inputs compared with sole legume cropping (Chikowo et al. 2020). Pigeon pea also improves soil structure through its extensive root system and the large amount of litter produced adds organic matter to the soil. Exudates from the roots have been shown to enhance phosphorus cycling efficiency in agricultural systems by unlocking fixed phosphorus (Nziguheba et al. 2016). By improving soil fertility, doubled-up legume intercropping reduces the fertilizer requirements for cereal crops grown in rotation by about $50 \%$, with minimum yield reduction (Chikowo et al. 2015; Rogé et al. 2016). Experiments in Malawi and Zambia have shown that maize grown in rotations and at $50 \%$ of the recommended nitrogen fertilizer produces yields comparable with maize receiving full fertilization (Chikowo et al. 2020).

Doubled-up legume technology has some limitations in terms of productivity and adoption of the practice. For example, areas with water limitations experience lower benefits due to poor pigeon pea performance in the intercrop (Smith et al. 2016). Farmers who cannot plant on time or effectively manage weeds may also fail to benefit from the technology. It is only with good management that the doubled-up legume intercropping technology can increase cereal productivity in crop sequences. As reported in a study conducted in Malawi, major bottlenecks to adopting doubled-up legume technology include the high cost of certified seeds, challenges with seed supply systems, high labor requirements, and limited access to lucrative markets (Kamanga et al. 2014).

\subsection{Conservation agriculture}

Conservation agriculture (CA) is practised on over 7.7 million hectares across Southern, East, and West Africa (Table 1). Conservation agriculture has three pillars: minimum soil discturbance, permanent soil cover with crop residues or live mulches (e.g., Fig. 1b), crop rotaion and intercroping (Lipper et al. 2014). All the three pillars potentially contribute to reducing GHG emissions and increasing sequestration of carbon in the soil. Continuous improvements in farming practices have given rise to innovative variants of CA (Giller et al. 2009).

The impact of CA on crop yield appears to be contextspecific. Seventeen of the studies reviewed evaluating crop yield under CA reported positive effects and eight reported nonsignificant effects, while one study reported a decrease in crop yield. Recent meta-analyses show that CA increases crop yield and yield stability in drylands (Rusinamhodzi et al. 2011; Pittelkow et al. 2015a, b). For example, in drylands of West Africa (Burkina Faso, Mali, Niger and Senegal), variants of CA (e.g., parkland trees associated with crops, coppicing trees, green manure, mulching, crop rotation and intercropping, and traditional soil/water conservation) can improve cereal yields by between 0.14 and $0.24 \mathrm{Mg} \mathrm{ha}^{-1}$, depending on tree species (Bayala et al. 2012). Long-term experiments in the drylands of Ethiopia and Southern Africa (Malawi, Mozambique, Zambia, and Zimbabwe) have also demonstrated that CA can increase grain yield relative to conventional agriculture (Thierfelder et al. 2015; Liben et al. 2018). Yield benefits become apparent $2-5$ years after adoption, when farmers have become more experienced in performing CA practices (Thierfelder et al. 2015). Yield benefits are attributed to soil fertility improvements through biological nitrogen fixation and increased retention of soil moisture. There are also context-specific benefits of CA, such as erosion control, biodiversity increase, weed suppression, carbon sequestration, and reversal of soil degradation processes that are common in conventional crop production systems (Hobbs et al. 2008).

Challenges associated with CA include low yields (Giller et al. 2009), which can be around $10 \%$ lower than with conventional practices (Pittelkow et al. 2015b), increased labor requirements when herbicides are not used (Grabowski and Kerr 2014), lack of mulch due to low productivity or priority being given to the use of crop residues as livestock feed over mulch (Giller et al. 2009), and use of herbicides that might be detrimental to biodiversity. To overcome the low yields, Vanlauwe et al. (2014) proposed appropriate use of mineral fertilizer as the fourth principle of CA. However, as shown by both modeling and empirical studies, the yield benefits of CA are context-specific (Pittelkow et al. 2015a). For example, Rosenstock et al. (2014) found that CA is highly unlikely to generate yield benefits for farmers in Kenya and Tanzania, while Liben et al. (2018) showed that the short- and medium-term effects of CA in Ethiopia depend on initial soil properties. They concluded that improved water infiltration and crop yield could occur in the short term, but short-term yield increases are less likely with moderate soil fertility in humid areas (Liben et al. 2018). Other limitations associated with CA include the prevalence of weeds that are difficult to control without tillage (Lee and Thierfelder 2017). This weed 
challenge leads to increased reliance on herbicides. The high initial cost of specialist equipment and competition for crop residues between CA and livestock feeding is also a major limitation for CA.

Despite the potential of CA to deliver multiple positive impacts after a few years, CA adoption remains very low in SSA $(<1 \%)$. This low adoption rate relates to the high variability in farmers' access to resources or specialist equipment. Giller et al. (2015) suggested that identifying and validating new technologies or practices which emphasise agronomy should become a "place-based" science. To enhance adoption, there is a need to apply general production ecology principles (theory) and agricultural development aspirations (direction) in specific local contexts and systems (Giller et al. 2015).

\subsection{Agroforestry practices}

Agroforestry, which is practised on 1.1 million $\mathrm{km}^{2}$ of land in SSA (Table 1), integrates trees and crops, trees and pasture/ livestock, or trees, crops, and pasture/livestock on the same area of land. A detailed definition of agroforestry and a general classification of agroforestry practices can be found in Sinclair (1999). The way in which the components of agroforestry are arranged and managed in the landscape constitutes agroforestry practice. Some agroforestry components/ technologies (e.g., improved fallow/green manure) are called cover crops. Because of their deep roots and year-round vegetation cover, agricultural systems with trees and shrubs are inherently more sustainable and efficient in using plant nutrients than annual systems without trees.

The impacts of agroforestry on crop yield, soil quality, and pest control are context-specific and depend on the ecological conditions, the type of tree species, and the type of crop. In principle, agroforestry maintains high-productivity levels by harnessing ecosystem services provided by trees (Kuyah et al. 2016). Several meta-analyses have demonstrated that agroforestry practices in SSA improve crop yields (Sileshi et al. 2008), reduce pest problems (Pumariño et al. 2015), increase soil fertility, reduce runoff and soil loss, and increase infiltration rate and soil moisture content (Kuyah et al. 2019; Muchane et al. 2020). Different meta-analyses have demonstrated that crop yields are almost double in agroforestry compared with non-agroforestry systems, while control of runoff is fivefold higher, soil losses are 10-fold lower, and infiltration is about threefold higher in agroforestry compared with nonagroforestry systems (Kuyah et al. 2019; Muchane et al. 2020). However, depending on the context and management practice, trade-offs between trees and crops regarding access to nutrients, water, and light can also be experienced (Kuyah et al. 2016, 2019). Agroforestry generally does well in humid and sub-humid areas but may bring in trade-offs in areas where moisture is limiting (Kuyah et al. 2019).
The most effective agroforestry practices for soil and water conservation involve contour hedgerows with multipurpose leguminous trees and shrubs such as Gliricidia sepium (Jacq.) Kunth ex Walp., Calliandra calothyrsus Meissn., and Leucaena trichandra (Zucc.) Urban (Kinama et al. 2007; Mutegi et al. 2008). In the highlands of Central Kenya, contour hedgerow systems consisting of Calliandra and Napier grass (Pennisetum purpureum Schumach.) are commonly used to control erosion, restore fertility, and sometimes improve crop yields (Kinama et al. 2007; Mutegi et al. 2008). Farmers who practise agroforestry for soil and water conservation can transform previously degraded land into productive and highyielding land (ibid.). Trees and shrubs in hedgerows may also be used as windbreaks and to control wind erosion in dry areas. However, trees tend to compete with crops when moisture is limiting or soils are infertile. Choosing the right tree, coupled with appropriate management such as pruning (trimming overgrown or unwanted branches or stems of a tree or a shrub), pollarding (cutting off the top and branches to encourage new growth at the top), or coppicing (cutting back a tree or shrub to ground level periodically, to stimulate growth), can minimize competition and eventual trade-offs (Kuyah et al. 2016).

Smallholder farmers who maintain a soil covering with trees or mulch from trees or cover crops increase the sustainability of their land. Cover crops and mulches have been used for decades in traditional farming systems in SSA. However, the practice has gained greater attention in recent years due to farming approaches such as CA with trees. Cover crops are planted to improve soil fertility, prevent soil erosion, and increase soil moisture content. Other documented benefits of cover crops in SSA include enhancing soil organic matter accumulation, weed suppression, and pest regulation (Daryanto et al. 2018). Perennial shrubs such as jack bean (Canavalia ensiformis (L.) DC.), sun hemp (Crotalaria juncea L.), and pigeon pea are preferred cover crop species because of their ability to fix nitrogen. Multipurpose leguminous tree species such as Leucaena spp., Gliricidia spp., Sesbania spp., and Calliandra spp. can also be lopped for mulch. Even though cover crops suitable for most farming systems and agroecological zones are available, they tend to compete with crops in areas where rainfall is limiting. Improved fallows are therefore preferred, since they utilise off-season resources. Improved fallows consist of leguminous trees and shrubs (e.g., Tithonia diversifolia (Hemsl.) A. Gray, Crotalaria grahamiana, Sesbania spp.) deliberately planted in rotation with cultivated crops to improve soil fertility through nutrient cycling and biological nitrogen fixation (Muchane et al. 2020). When properly managed, improved fallows can increase maize yields to about $6 \mathrm{Mg} \mathrm{ha}^{-1}$ (Partey et al. 2017) and conserve soil moisture for crop production (Sileshi et al. 2014).

Several previous studies suggest that the adoption of agroforestry has not matched its promise. In fact, in some cases, 
some agroforestry technologies have been abandoned because farmers did not obtain the intended benefits (Kiptot et al. 2007). Several factors constrain agroforestry adoption in SSA, with farmers' knowledge, attitudes, and perceptions playing a crucial role (Meijer et al. 2015). Other factors include high cost of establishment, reduced productivity due to competition for growth resources, favorable conditions that attract birds, primates and other pests and diseases, reduced area for crop production, unavailability of planting material, and delayed returns on investment. Planting multipurpose trees (e.g., fertilizer, fodder, timber, fruit trees) can help offset some of the trade-offs (Kuyah et al. 2020). A consideration when recommending agroforestry for smallholders is that it requires some investment in terms of inputs (seedlings) and time, since the benefits and co-benefits as products and services will not be experienced until after several seasons. Incentive schemes during the establishment year can be catalytic, as can including annual crops or forage species that yield crop and livestock products already in the first year.

\subsection{Planting basins}

Planting basins involve digging holes and planting crops to concentrate nutrients and water close to the plant. A unique form of planting basin known as zaï pits is common in the Sahel. Zaï pits are usually dug during the dry season and filled with one or two handfuls of dry dung, corresponding to 1$3 \mathrm{Mg}$ dry organic matter ha ${ }^{-1}$ (Roose et al. 1999; Amede et al. 2011). Three to four seeds of sorghum or millet are sown per pit after the first rain.

Zaï pits have been used successfully in the Sahel for many years and are becoming more popular in East and Southern Africa. Similar technology with planting pits has been used in different regions, for example, tassa in Niger and Mali (Zougmoré et al. 2014), ngoro in Tanzania (Malley et al. 2004), and katumani pits in Kenya. Planting basins increase crop yield, improve soil quality and improve input use efficiency (Table 1). In Burkina Faso, zaï pits can increase yields by up to $1.5 \mathrm{Mg} \mathrm{ha}^{-1}$ in years when rainfall is good (Roose et al. 1999). Use of manure with zaï pits in Burkina Faso more than doubles grain yield relative to pits without manure (Fatondji et al. 2006). In the Ethiopian highlands, zaï pits combined with nitrogen inputs have been shown to increase potato yields by between 500 and $2000 \%$, and yield of beans by up to $250 \%$, compared with control plots (Amede et al. 2011). Farmers have adapted planting basins by increasing their depth and width. For example, the use of $2 \mathrm{~m}$ wide ngoro pits in Tanzania gave more maize grain yield $\left(1.9 \mathrm{Mg} \mathrm{ha}^{-1}\right)$ compared with $1.5 \mathrm{~m}$ wide pits $\left(1.7 \mathrm{Mg} \mathrm{ha}^{-1}\right)$ and $1 \mathrm{~m}$ wide pits (1.44 $\mathrm{Mg} \mathrm{ha}^{-1}$ ) (Malley et al. 2004). Planting basins create wet conditions that can have an impact on GHG emissions. Specifically, concentrating nutrients in one spot can create hotspots of GHG emissions. On the other hand, planting basins may improve nutrient use efficiency, as all nutrients are placed close to the plant and within reach of plant roots. No studies relating planting basin to pests and diseases are available in the literature, and therefore, we cannot provide a clear link between planting pits and pests. This shows that practices reviewed respond to certain challenges and not all.

Farmers have found planting basins to be attractive because they reduce the risk of crop loss and provide more options for cropping and bringing into cultivation land previously not suitable for cultivation (Roose et al. 1999; Amede et al. 2011; Zougmoré et al. 2014). However, it is essential to note that digging planting pits is labor-intensive and may represent a shift in labor inputs from men to women in regions where plowing is done by men who use oxen, while women are tasked with digging planting basins (Dahlin and Rusinamhodzi 2019). A shift in labor represents both a risk to women and an opportunity for women's empowerment. Women in programs that use planting basins devise strategies for easing labor through cooperatives. In eastern Kenya, a challenge to planting basins is that farmers prefer maize, even though crops that can occasionally withstand wet and dry soils (e.g., sorghum or pearl millet) are best suited for planting basins. Maize is not suitable, as it is not tolerant of drought or waterlogging (pits are prone to waterlogging during wet years). Another limitation concerns farmer knowledge on the preparation and use of manure. Some farmers apply untreated (fresh) cow dung to planting pits, negatively affecting the emerging crops.

Adoption of planting basins has been low to date, despite widespread diffusion of the practice (Danso-Abbeam et al. 2019). A major bottleneck to greater adoption of planting basins is the high labor requirement. For instance, $450 \mathrm{~h}$ are needed for digging zaï pits on an area of $1 \mathrm{ha}$, and $150 \mathrm{~h}$ are needed for applying fertilizer in the dug pits (Kaboré and Reij 2004). The high labor requirements make the technology unattractive for resource-constrained farmers incapable of employing additional labor. Large-scale application of planting basins has also been hindered by lack of financial or education support to poor or subsisting farmers. Farm-level policies that aim to increase access to extension services, credit facilities, and the facilitation of farmer groups can improve the adoption of planting basins (Danso-Abbeam et al. 2019).

\subsection{Push-pull technology}

Push-pull is an innovative cropping system developed for pest management in SSA (Fig. 1d). It has already been adopted by over 237,670 farmers in East Africa (http://www.push-pull. net/adoption.shtml). The practice was initially developed to control stemborers (Chilo partellus Swinhoe and Busseola fusca Fuller) but has also been shown to control striga weed (Khan et al. 2002). Recently, push-pull was shown to effectively control the invasive fall armyworm (Spodoptera 
frugiperda J.E. Smith) (Midega et al. 2018). Push-pull involves intercropping a cereal crop with silverleaf (Desmodium uncinatum Jacq.) or greenleaf (Desmodium intortum Mill.) desmodium as a push crop and planting Napier grass (Pennisetum purpureum Schumach.) or brachiaria (Brachiaria brizantha (Hochst. ex A. Rich.) Stapf.) as a border crop (Khan et al. 2014). Desmodium releases two chemicals, one of which repels stemborer moths and attracts their natural enemies, while the other prevents striga from attaching to the maize roots. Napier grass attracts stemborer moths, which lay their eggs on it. When the eggs hatch, the Napier grass releases a sticky substance that limits insect movement, killing the larvae or juvenile stemborers. Desmodium, a perennial plant, is maintained by trimming before planting to minimize competition with the young cereal. It can also be trimmed once or twice during the growing season to provide fodder or mulch. When harvesting the Napier grass, at least one fully grown row is retained to maintain the "pull" service. Other benefits of push-pull include fodder provision, soil erosion control, and soil fertility improvement (Midega et al. 2015).

Push-pull is known to control pests and increase crop yield (Table 1). Several studies show that push-pull is superior in controlling constraints to crop production compared with the traditional cereal-legume intercropping that is a fundamental component of mixed farming systems in Kenya, parts of Uganda, Tanzania and Ethiopia (Khan et al. 2014; Midega et al. 2015). Long-term experiments in these countries show that push-pull can effectively control pests (striga, stem-borer, fall armyworm) and improve soil fertility. In studies comparing push-pull intercrop versus maize or sorghum monocrop (Khan et al. 2006; Midega et al. 2015), desmodium effectively eliminated striga, reducing the weed to negligible amounts. Desmodium suppresses striga through suicidal germination, reducing the seed bank in the soil, shading, and increasing available nitrogen via nitrogen fixation (Khan et al. 2002). The effectiveness of desmodium against striga has been demonstrated in East Africa, where striga is a major constraint to cereal production, and where the intercropping of cereals with legumes such as common beans, soybean, and cowpea has not eliminated the problem of striga in the region (Khan et al. 2006, 2009). Good efficacy of desmodium against striga and stemborer has been demonstrated on including common beans or cowpea in maize-desmodium intercrops (Khan et al. 2006, 2009).

With the integration of drought-tolerant desmodium species, push-pull has evolved into a climate-smart technology that performs well under dry conditions and adapts to common intercropping systems in East Africa. Drought-tolerant desmodium species have been found to effectively suppress parasitic striga weed and improve cereal grain yields in western Kenya (Midega et al. 2015, 2018). Push-pull practices involving $D$. intortum and brachiaria (Mulatto II cultivar) are well adapted to dry areas in western Kenya, eastern Uganda, and northern Tanzania (Midega et al. 2015, 2018). Push-pull has also been integrated into common cereal cropping systems in East Africa.

Even though push-pull has multiple benefits, the high cost of desmodium seeds and insufficient flow of information and training of farmers due to lack of specialist skills have limited farmers' awareness and adoption (Murage et al. 2015). The adoption of push-pull has therefore been slow, despite its great promise. Its uptake has been faster in regions affected by striga. In environments where striga is not a challenge, farmers are often reluctant to replace legumes (e.g., common beans, cowpea, and groundnuts) with fodder species (desmodium) or to reduce maize production area in favor of Napier grass or brachiaria (Kebede et al. 2018). In this case, ownership of livestock and/or the presence of a market for fodder might drive adoption (Ndayisaba et al. 2020). Another example of a driver of adoption is the zero grazing policy in countries like Rwanda, which has created a need to cut and carry fodder to enclosed animals. This policy encourages crop-livestock farmers to find additional niches for fodder production on their farms. Another constraint is the low availability of certified desmodium seeds (Murage et al. 2015). This calls for actions addressing the lack of seeds of both desmodium and Napier grass/brachiaria at farm gates.

\subsection{Fertilizer and manure micro-dosing}

Traditionally, farmers broadcast manure and fertilizers to supply nutrients to crops. Such approaches are inefficient but common in smallholder systems in SSA. In contrast, microdosing administers small amounts of the nutrient source at the right time and close to the seedlings (Tabo et al. 2007; Twomlow et al. 2010). It is widely considered an entry point to sustainable intensification of agricultural systems in dry areas (Twomlow et al. 2010; Adams et al. 2016; Ibrahim et al. 2016a). The practice was first tested in the Sahel (Burkina Faso, Mali, and Niger) and subsequently popularized in Southern Africa (e.g., in Mozambique, South Africa, and Zimbabwe). In practice, a bottle capful or three-finger pinch of fertilizer is placed in a sowing hole or beside a plant (Twomlow et al. 2010). The application of small amounts of fertilizer appeals to farmers because of a good return on investment and low financial risk (Aune et al. 2007; Hayashi et al. 2008). The amount of fertilizer used in micro-dosing is close to one-third of the recommended rate, suggesting efficiency and ability to minimize fertilizer inputs (Hayashi et al. 2008; Ibrahim et al. 2015).

Fertilizer micro-dosing originally targeted maize (Ncube et al. 2007; Twomlow et al. 2010; Tovihoudji et al. 2017), sorghum (Aune et al. 2007), and millet (Ibrahim et al. 2015, 2016a, b; Adams et al. 2016) but has recently been expanded to rice (Vandamme et al. 2018). The technology has increased 
productivity in areas where high costs previously discouraged poor farmers from using fertilizers (Hayashi et al. 2008; Ibrahim et al. 2015). Cases of increased household income have also been reported (Ibrahim et al. 2015). Increased short-term crop yield across the Sahel has led to upscaling of micro-dosing as an agronomic practice in low-input cropping systems (Adams et al. 2016). A meta-analysis with 165 paired yield outcomes from 33 study sites in 11 countries across SSA reported that micro-dosing improved grain yields by $47 \%$ relative to management with no nutrient inputs (Tonitto and Ricker-Gilbert 2016). Experiments on nutrient-depleted farms in Niger, Mali, and Burkina Faso resulted in greater average grain yield of millet and sorghum (44-120\%) compared with fertilizer broadcasting methods and other farm practices (Tabo et al. 2007; Bielders and Gérard 2015). More significant yield increases have been observed comparing fertilizer microdosing with unfertilized control plots (Aune et al. 2007; Hayashi et al. 2008; Twomlow et al. 2010; Ibrahim et al. 2016b). Micro-dosing has been found to counter the negative impacts of late sowing in semi-arid and arid areas (Bielders and Gérard 2015). The positive effects of fertilizer microdosing on yield arise from better exploitation of soil nutrients because of the early production of many lateral roots within the topsoil (Ibrahim et al. 2016b). Micro-dosing also enables plants to grow fast and evade droughts that may occur early in the season. Plants with fast-growing roots can efficiently exploit moisture at greater depths later in the season when soil moisture near the soil surface is low.

While yield benefits, economic returns, and positive farmers' perception on micro-dosing have been reported in many countries (Ncube et al. 2007; Tonitto and RickerGilbert 2016; Vandamme et al. 2018), the technology has limitations and trade-offs that need to be overcome (Hayashi et al. 2008; Twomlow et al. 2010). Manual micro-dosing is laborintensive and time-consuming, particularly when sowing and micro-dosing are performed in separate operations (Vandamme et al. 2018). Labor demand can be reduced if the technology is mechanized, allowing simultaneous seed sowing and fertilizer application, packaging appropriate fertilizers in small packs, or seed coating with fertilizer (Vandamme et al. 2018). Another limitation of fertilizer micro-dosing is nutrient mining. Evidence from Benin, Mali, and Niger shows that fertilizer micro-dosing enhances crop yields but increases the risk of soil nutrient depletion in low-input cropping systems (Ibrahim et al. 2016a; Tovihoudji et al. 2017). The risk of soil nutrient depletion is generally higher for phosphorus and potassium (Tovihoudji et al. 2017) since these minerals cannot be fixed biologically from the atmosphere by plants. There is also the risk of soil nutrient imbalances if crop nutrient uptake exceeds the amount added through micro-dosing (Nziguheba et al. 2016). Consequently, crop yield is higher at the beginning of fertilizer micro-dosing but eventually declines as crop response to fertilizer wanes over time (Adams et al. 2016; Tovihoudji et al. 2017). Nutrient mining and nutrient imbalances can be averted by combining micro-dosing with organic amendments, e.g., use of organic manure or compost (Ibrahim et al. 2016a; Tonitto and Ricker-Gilbert 2016), or complementing it with sustainable practices such as intercropping with nitrogenfixing legumes or retaining crop residues (Ibrahim et al. 2016a).

Studies conducted in West and Southern Africa suggest that micro-dosing adoption requires conducive and supportive institutional arrangements and input and output market linkages (Mwinuka et al. 2017). Current institutional arrangements limit access to fertilizer, credits, training, and information flow to farmers, creating bottlenecks to adopting microdosing. Compared with recommended levels, micro-dosing produces lower yields and is less profitable (Ibrahim et al. 2016a). Reduced profitability, coupled with other institutional constraints, limits the adoption of the technology. Microdosing is currently limited to cereal monocrops and has not been tested for intercropping or mixed cropping systems characteristic of smallholder farmers in SSA.

\section{Potential for reducing the carbon footprint of agriculture}

Africa's contribution to global carbon emissions is mainly driven by a rapidly increasing population causing cropland expansion, land degradation, and increased deforestation risks (Ciais et al. 2011). The net release of carbon from land-use change and forestry in SSA is estimated to be $0.24 \mathrm{Pg} \mathrm{C}_{\text {year }}{ }^{-1}$ (Ciais et al. 2011). Agriculture is the second-largest contributor to $\mathrm{GHG}$ emissions in terms of $\mathrm{CO}_{2}$ eq. (Fig. 5), contributing about $31 \%$ of Africa's total emissions. Agricultural GHG emissions in the region are projected to increase, while the energy sector's GHG contributions are expected to decrease by 2050 (Fig. 5 b).

The agronomic practices reviewed here show large yet varying potential for offsetting GHG emissions from agriculture. Most practices can lower emission intensities by increasing the amount of carbon stored in the soil (e.g., intercropping, CA, agroforestry) and biomass (e.g., agroforestry). For example, intercropping and CA have been suggested as practices that potentially increase soil organic carbon in dryland conditions (Hobbs et al. 2008). On sandy soils of SSA, technologies that increase soil water retention (thus increasing crop productivity) may significantly increase soil carbon sequestration (Nkurunziza et al. 2019). Furthermore, tree species used in various agroforestry practices sequester significant amounts of carbon in biomass and soil. Table 2 shows the estimated carbon uptake in a 20-year rotation cycle.

The agronomic practices reviewed can lower emission intensities by reducing direct and indirect soil $\mathrm{N}_{2} \mathrm{O}$ emissions. In croplands, high $\mathrm{N}_{2} \mathrm{O}$ emissions result from adding extra nitrogen inputs in the form of organic nitrogen (e.g., practices 
Table 2 Mean annual increment (MAI, $\mathrm{C} \mathrm{ha}^{-1}$ year $^{-1}$ ) rate and carbon dioxide equivalents $\left(\mathrm{t}_{\mathrm{Cha}}^{-1} \mathrm{CO}_{2}\right.$ eq.) in tree biomass estimated assuming a 20year rotation in various agroforestry practices and forests/woodlands in Southern Africa

\begin{tabular}{|c|c|c|c|c|c|c|}
\hline Agroforestry practice & Species & Country & Age (years) & MAI & $\mathrm{CO}_{2}$ eq. $\left(\mathrm{t} \mathrm{ha}^{-1}\right)$ & Reference $^{*}$ \\
\hline \multirow[t]{3}{*}{ Improved fallow } & Tephrosia vogelii & Zambia & 3 & 2.8 & NA & 1 \\
\hline & Sesbania sesban & Zambia & 3 & 2.7 & NA & 1 \\
\hline & Cajanus cajan & Zambia & 3 & 2.5 & NA & 1 \\
\hline \multirow[t]{4}{*}{ Intercropping } & Leucaena leucocephala & Zambia & 10 & 3.2 & 234.9 & 1 \\
\hline & Gliricidia sepium & Zambia & 10 & 2.9 & 212.9 & 1 \\
\hline & Calliandra calothyrsus & Zambia & 10 & 2.7 & 198.2 & 1 \\
\hline & Senna siamea & Zambia & 10 & 2.6 & 190.8 & 1 \\
\hline Parkland & Faidherbia albida & Tanzania & 6 & 1.2 & 88.1 & 2 \\
\hline \multirow[t]{14}{*}{ Woodlots } & Acacia auriculiformis & Tanzania & 5 & 2.3 & 168.8 & 3 \\
\hline & Acacia crassicarpa & Tanzania & 5 & 5.1 & 374.3 & 3 \\
\hline & Acacia julifera & Tanzania & 5 & 3.1 & 227.5 & 3 \\
\hline & Acacia leptocarpa & Tanzania & 5 & 3.8 & 278.9 & 3 \\
\hline & Acacia mangium & Tanzania & 5 & 3.8 & 278.9 & 3 \\
\hline & Acacia nilotica & Tanzania & 5 & 2.3 & 168.8 & 3 \\
\hline & Acacia polyacantha & Tanzania & 5 & 3.6 & 264.2 & 3 \\
\hline & Gliricidia sepium & Tanzania & 5 & 2.9 & 212.9 & 3 \\
\hline & Leucaena diversifolia & Tanzania & 5 & 3.4 & 249.6 & 3 \\
\hline & Leucaena pulverulenta & Zambia & 7 & 8.0 & 587.2 & 4 \\
\hline & Leucaena collinsii & Zambia & 7 & 4.3 & 315.6 & 4 \\
\hline & Leucaena diversifolia & Zambia & 7 & 4.7 & 345.0 & 4 \\
\hline & Leucaena leucocephala & Zambia & 7 & 4.6 & 337.6 & 4 \\
\hline & Leucaena macrophylla & Zambia & 7 & 3.5 & 256.9 & 4 \\
\hline
\end{tabular}

${ }^{¥}$ References represent the sources of carbon accumulation rates: 1 = Kaonga and Coleman (2008); 2 = Okorio and Maghembe (1994); $3=$ Kimaro et al. (2011); 4 = Kaonga and Bayliss-Smith (2009); NA = not applicable because rotations for improved fallow only take 2-3 years

including nitrogen-fixing plants with nitrogen-rich plant residues) or inorganic nitrogen (Valentini et al. 2013). Generally, crops that receive a lot of fertilizer (e.g., cereal monocultures) have a high carbon footprint, while those that fix nitrogen and are not fertilized or receive less fertilizer (e.g., legumes) typically have a small carbon footprint. For example, conventionally produced maize in South Africa is estimated to have a carbon footprint as low as $0.6 \mathrm{t} \mathrm{CO}_{2}$ eq. ha ${ }^{-1}$ (Tongwane et al. 2016). In Zambia, average annual emissions from maize production at three different intensities of nitrogen fertilizer use $(0,25,85 \mathrm{~kg}$ $\mathrm{N} \mathrm{ha}^{-1}$ ) were estimated to range between 0.1 and $0.6 \mathrm{t} \mathrm{CO}_{2}$ eq. $\mathrm{ha}^{-1}$ (FAO 2015). On the other hand, leaf biomass from agroforestry when applied at $5 \mathrm{Mg} \mathrm{ha}^{-1}$ can provide $\mathrm{N}$ inputs of 60 $150 \mathrm{~kg} \mathrm{ha}^{-1}$, and this can support maize yields of up to $4 \mathrm{Mg}$ $\mathrm{ha}^{-1}$ without any added synthetic fertilizer (Sileshi et al. 2014). In Gliricidia-maize intercropping in Malawi, Kim (2012) demonstrated the possibility to reduce synthetic fertilizer use by $48 \mathrm{~kg} \mathrm{~N} \mathrm{ha}^{-1}$ year $^{-1}$ while still maintaining yields of up to $4 \mathrm{Mg} \mathrm{ha}^{-1}$ and avoiding GHG emissions amounting to $0.48 \mathrm{~kg} \mathrm{~N}_{2} \mathrm{O} \mathrm{ha}{ }^{-1}$ year $^{-1}$ (Kim 2012). The system was also estimated to mitigate 3.5-4.1 t CO 2 eq. ha ${ }^{-1}$ year $^{-1}$ (Kim 2012).

Soil $\mathrm{N}_{2} \mathrm{O}$ emissions from African agroforestry $\left(4.7 \mathrm{~kg} \mathrm{~N}_{2} \mathrm{O}\right.$ $\mathrm{ha}^{-1}$ year $\left.^{-1}\right)$ are comparable with those from croplands $(4.0 \mathrm{~kg}$
$\mathrm{N}_{2} \mathrm{O} \mathrm{CO}_{2}$ ha $^{-1}$ year $^{-1}$ ) (Kim et al. 2016). However, soils under agroforestry are reported to be net $\mathrm{CH}_{4}$ sinks. For instance, according to a recent synthesis (Kim et al. 2016), soils under agroforestry oxidize $1.6 \mathrm{~kg} \mathrm{CH}_{4} \mathrm{ha}^{-1}$ year ${ }^{-1}$. The most considerable reduction in net $\mathrm{CH}_{4}$ emissions has been recorded under improved fallow, with net soil $\mathrm{CH}_{4}$ emissions being reduced with a shift from cropping to agroforestry systems (Kim et al. 2016).

Legumes used in push-pull technology, cereal-legume intercropping, and doubled-up legume technology reduce reliance on nitrogen fertilizer inputs and lower the GHG cost of fertilizer production. Push-pull practices can also reduce emissions related to the production of herbicides and pesticides that would otherwise be needed to control stem-borer, fall armyworm, and striga. However, as shown by a study conducted in Denmark, leguminous plants can be a source of $\mathrm{N}_{2} \mathrm{O}$ from legume-derived nitrogen, especially during residue decomposition (Pugesgaard et al. 2017).

Micro-dosing customizes the addition of nutrients to plant uptake, thereby reducing emissions of $\mathrm{N}_{2} \mathrm{O}$. Direct and indirect soil $\mathrm{N}_{2} \mathrm{O}$ emissions and $\mathrm{CO}_{2}$ from fertilizer and machinery manufacturing (in the case of mechanized micro-dosing) and $\mathrm{CO}_{2}$ from field operations can be expected to be lower 
than those associated with fertilizer banding or broadcasting. Planting basins and push-pull technology reduce GHG emissions as they result in a decrease in the overall area under tillage and thus reduce the amounts of fuel-based GHG emissions on farms. Significant data gaps exist regarding the contribution of specific innovations such as push-pull to carbon sequestration and GHG emission reductions related to crop protection products.

\section{Conclusions and recommendations}

The agronomic practices identified here are important because they can simultaneously increase crop productivity and, in certain situations, support provisioning of other ecosystem services, while also reducing the carbon footprint of agriculture. Uptake of these agronomic practices can transform existing crop management and contribute to sustainable intensification in regions where they are not yet adopted. Agroforestry, legume-cereal intercropping, and push-pull are diverse systems and harness ecosystem services from perennials to increase productivity. These innovations can also diversify and increase household incomes from increased crop yields and improved resource use. For example, CA and planting basins conserve water, while planting basins and microdosing can improve nutrient targeting and reduce input costs.

Regardless of the capacity of technological or management innovations to increase crop yields and incomes, they will have limited impacts if not adopted at scale. To achieve large-scale adoption, there is a need to overcome barriers to adoption, namely, limited financing, lack of a supportive policy and regulatory environment, lack of specialist extension services, shortage of labor, lack or high cost of inputs such as seeds or planting material, and low degree of mechanization (Kamanga et al. 2014; Murage et al. 2015; Dahlin and Rusinamhodzi 2019; Danso-Abbeam et al. 2019). Policy and regulatory authorities need to formulate creative policies and regulations that incentivize the adoption of promising options. For example, policies that ensure reduction in taxes and, consequently, retail prices for critical fertilizers may improve affordability and access to fertilizer inputs and incentivize their use by smallholder farmers. Lack of financial resources to cover input costs can be tackled through creative financing (Lipper et al. 2014). For instance, good availability of low-cost credit facilities for farmers, linked to technology adoption and guaranteed expert support services, can promote adoption and ensure access to crucial knowledge.

One major challenge in smallholder agriculture is its overreliance on family labor. Rural-urban migration and a general lack of interest in agriculture among the young generation result in labor shortages that may limit adoption of labor-demanding innovations such as doubled-up legume, push-pull, fertilizer, and manure micro-dosing. To overcome the labor challenges, there is a need to develop and promote labor-saving equipment and mechanization as an essential aspect of sustainable intensification of smallholder agriculture in SSA. Considering the challenges in access to information and training of farmers (for technologies that require specialist skills), there may be an opportunity to recruit unemployed local young people to rapid training courses covering the essentials of extension work and then employing them as para-extension workers. These para-extension workers could initially be restricted to the main agricultural products grown in specific locations and improvements based on new research findings. Accessibility of farmer support services could help farmers embrace GAP, especially in communities that consume what they produce locally.

Finally, the management and technological approaches identified here can contribute to food security and improve livelihoods in the SSA region. However, synergies must be explored to maximize benefits derived from combining the various innovations. For example, fertilizer micro-dosing can be combined with basin planting (e.g., zaï pits). Planting basins can also be beneficially combined with contour or stone bunds and agroforestry practices (Bayala et al. 2012). Specific CA practices, such as crop rotation, intercropping with legume cover crops, and no-till ridging, can be adapted in different farming systems by smallholders who do not have the resources to buy herbicide or mechanize farm power. We recommend policy advocacy, input financing, capacity development, and strengthening extension advisory services to achieve large-scale adoption of these practices.

Authors' contributions Shem Kuyah and Gudeta W. Sileshi designed the structure and formulated the aims of the manuscript. Libère Nkurunziza, Ngonidzashe Chirinda, Pierre Celestin Ndayisaba, Kangbéni Dimobe, and Ingrid Öborn contributed to the data analysis, literature review, and writing and editing of different sections of the manuscript.

Funding Open access funding provided by Swedish University of Agricultural Sciences.

Data availability Not applicable.

Code availability Not applicable.

\section{Declarations}

Conflict of interest The authors declare that they have no conflict of interest.

\section{Consent for publication Not applicable.}

Open Access This article is licensed under a Creative Commons Attribution 4.0 International License, which permits use, sharing, adaptation, distribution and reproduction in any medium or format, as long as you give appropriate credit to the original author(s) and the source, provide a link to the Creative Commons licence, and indicate if changes were made. The images or other third party material in this article are included in the article's Creative Commons licence, unless indicated otherwise in a credit line to the material. If material is not included in the article's 
Creative Commons licence and your intended use is not permitted by statutory regulation or exceeds the permitted use, you will need to obtain permission directly from the copyright holder. To view a copy of this licence, visit http://creativecommons.org/licenses/by/4.0/.

\section{References}

Abate T, Fisher M, Abdoulaye T, Kassie GT, Lunduka R, Marenya P, Asnake W (2017) Characteristics of maize cultivars in Africa: how modern are they and how many do smallholder farmers grow? Agricult Food Secur 6:30. https://doi.org/10.1186/s40066-0170108-6

Adams AM, Gillespie AW, Kar G, Koala S, Ouattara B, Kimaro AA, Bationo A, Akponikpe PBI, Schoenau JJ, Peak D (2016) Long term effects of reduced fertilizer rates on millet yields and soil properties in the West-African Sahel. Nutr Cycl Agroecosyst 106:17-29. https://doi.org/10.1007/s10705-016-9786-x

AGRA (2017) Africa agriculture status report: the business of smallholder agriculture in sub-Saharan Africa. Alliance for a Green Revolution in Africa (AGRA), Nairobi

Amede T, Menza M, Awlachew SB (2011) Zai improves nutrient and water productivity in the Ethiopian highlands. Exp Agric 47:7-20. https://doi.org/10.1017/S0014479710000803

Arslan A, Mccarthy N, Lipper L et al (2015) Climate Smart Agriculture? Assessing the adaptation implications in Zambia. J Agric Econ 66: 753-780. https://doi.org/10.1111/1477-9552.12107

Assefa T, Jha M, Reyes M, Tilahun S, Worqlul A (2019) Experimental evaluation of conservation agriculture with drip irrigation for water productivity in sub-Saharan Africa. Water (Switzerland) 11. https:// doi.org/10.3390/w11030530

Aune JB, Doumbia M, Berthe A (2007) Microfertilizing sorghum and pearl millet in Mali: agronomic, economic and social feasibility. Outlook Agricult 36:199-203. https://doi.org/10.5367/ 000000007781891504

Baudron F, Mamo A, Tirfessa D, Argaw M (2015) Impact of farmland exclosure on the productivity and sustainability of a mixed croplivestock system in the central rift valley of Ethiopia. Agric Ecosyst Environ 207:109-118. https://doi.org/10.1016/j.agee.2015. 04.003

Bayala J, Sileshi G, Coe R et al (2012) Cereal yield response to conservation agriculture practices in drylands of West Africa: a quantitative synthesis. J Arid Environ 78:13-25. https://doi.org/10.1016/j. jaridenv.2011.10.011

Belay SA, Schmitter P, Worqlul AW, Steenhuis TS, Reyes MR, Tilahun SA (2019) Conservation agriculture saves irrigation water in the dry monsoon phase in the Ethiopian highlands. Water (Switzerland) 11: 2103. https://doi.org/10.3390/w11102103

Bielders CL, Gérard B (2015) Millet response to microdose fertilization in south-western Niger: effect of antecedent fertility management and environmental factors. Field Crop Res 171:165-175. https://doi. org/10.1016/j.fcr.2014.10.008

Blaser WJ, Oppong J, Hart SP, Landolt J, Yeboah E, Six J (2018) Climate-smart sustainable agriculture in low-to-intermediate shade agroforests. Nature Sustain 1:234-239. https://doi.org/10.1038/ s41893-018-0062-8

Bruinsma J (2009) The resource outlook to 2050: by how much do land, water and crop yields need to increase by 2050 . In: In: Expert meeting on how to feed the world in 2050. Economic and Social Development Department, Food and Agriculture Organization of the United Nations, New York

Calzadilla A, Zhu T, Rehdanz K et al (2009) Economywide impacts of climate change on agriculture in Sub-Saharan Africa. International Food Policy Research Institute, Washington, D.C
Chikowo R, Zingore S, Nyamangara J et al (2015) Approaches to reinforce crop productivity under rain-fed conditions in sub-humid environments in sub-Saharan Africa. In: Lal R, Singh BR, Mwaseba LD et al (eds) Sustainable intensification to advance food security and enhance climate resilience in Africa. Springer, Switzerland, pp 235-253

Chikowo R, Chimonyo V, Gwenambira C, Snapp S (2020) Ecosystem services in doubled-up legume systems. In: Rusinamhodzi L (ed) The role of ecosystem services in sustainable food systems. Elsevier, Amsterdam, pp 171-180

Chilagane EA, Saidia PS, Kahimba FC, Asch F, Germer J, Graef F, Swai E, Rweyemamu CL (2020) Effects of fertilizer micro-dose and in situ rain water harvesting technologies on growth and yield of pearl millet in a semi-arid environment. Agricult Res 9:609-621. https:// doi.org/10.1007/s40003-020-00454-7

Chimonyo VGP, Snapp SS, Chikowo R (2019) Grain legumes increase yield stability in maize-based cropping systems. Crop Sci 59:12221235. https://doi.org/10.2135/cropsci2018.09.0532

Ciais P, Bombelli A, Williams M, Piao SL, Chave J, Ryan CM, Henry M, Brender P, Valentini R (2011) The carbon balance of Africa: synthesis of recent research studies. Philos Trans R Soc A Math Phys Eng Sci 369:2038-2057. https://doi.org/10.1098/rsta.2010.0328

Corbeels M, Cardinael R, Naudin K, Guibert H, Torquebiau E (2019) The 4 per 1000 goal and soil carbon storage under agroforestry and conservation agriculture systems in sub-Saharan Africa. Soil Tillage Res 188:16-26. https://doi.org/10.1016/j.still.2018.02.015

Coulibaly A, Woumou K, Aune JB (2019) Sustainable intensification of sorghum and pearl millet production by seed priming, seed treatment and fertilizer microdosing under different rainfall regimes in Mali. Agronomy 9:664. https://doi.org/10.3390/agronomy9100664

D'Annolfo R, Gemmill-Herren B, Amudavi D et al (2020) The effects of agroecological farming systems on smallholder livelihoods: a case study on push-pull system from Western Kenya. Int J Agric Sustain 19:56-70. https://doi.org/10.1080/14735903.2020.1822639

Dahlin AS, Rusinamhodzi L (2019) Yield and labor relations of sustainable intensification options for smallholder farmers in sub-Saharan Africa. A meta-analysis. Agron Sustain Dev 39:32. https://doi.org/ 10.1007/s13593-019-0575-1

Danso-Abbeam G, Dagunga G, Ehiakpor DS (2019) Adoption of Zai technology for soil fertility management: evidence from Upper East region, Ghana. J Econ Struct 8:32. https://doi.org/10.1186/ s40008-019-0163-1

Daryanto S, Fu B, Wang L, Jacinthe PA, Zhao W (2018) Quantitative synthesis on the ecosystem services of cover crops. Earth Sci Rev 185:357-373. https://doi.org/10.1016/j.earscirev.2018.06.013

De Bauw P, Vandamme E, Senthilkumar K et al (2019) Combining phosphorus placement and water saving technologies enhances rice production in phosphorus-deficient lowlands. Field Crop Res 236: 177-189. https://doi.org/10.1016/j.fcr.2019.03.021

Demissie G, Mendesil E, Diro D, Tefera T (2019) Effect of crop diversification and mulching on termite damage to maize in western Ethiopia. Crop Prot 124:104723. https://doi.org/10.1016/j.cropro. 2019.01.029

Diatta AA, Abaye O, Thomason WE, Lo M, Thompson TL, Vaughan LJ, Gueye F, Diagne N (2020) Evaluating pearl millet and mungbean intercropping in the semi-arid regions of Senegal. Agron J 112: 4451-4466. https://doi.org/10.1002/agj2.20341

Drinkwater LE, Wagoner P, Sarrantonio M (1998) Legume-based cropping systems have reduced carbon and nitrogen losses. Nature 396:262-265. https://doi.org/10.1038/24376

Droppelmann KJ, Snapp SS, Waddington SR (2017) Sustainable intensification options for smallholder maize-based farming systems in sub-Saharan Africa. Food Secur 9:133-150. https://doi.org/10.1007/ s12571-016-0636-0

Falconnier GN, Descheemaeker K, Mourik TA, Giller KE (2016) Unravelling the causes of variability in crop yields and treatment responses for better tailoring of options for sustainable 
intensification in southern Mali. Field Crop Res 187:113-126. https://doi.org/10.1016/j.fcr.2015.12.015

FAO (2015) Climate change mitigation and smallholder agriculture in Zambia. Policy Brief No. 3. Food and Agriculture Organization of the United Nations (FAO), Rome

FAO (2019) FAOSTAT Emissions Database, Agriculture, Agriculture Total. In: Food and Agriculture Organization of the United Nations (FAO) http://faostat3.fao.org/download/G1/GT/E.

FAO, ITPS (2015) Status of the World's Soil Resources (SWSR) - Main Report. Prepared by Intergovernmental Technical Panel on Soils (ITPS). Food and Agriculture Organization of the United Nations (FAO), Rome

Fatondji D, Martius C, Bielders CL, Vlek PLG, Bationo A, Gerard B (2006) Effect of planting technique and amendment type on pearl millet yield, nutrient uptake, and water use on degraded land in Niger. Nutr Cycl Agroecosyst 76:203-217. https://doi.org/10. 1007/s10705-005-6209-9

Franke AC, van den Brand GJ, Vanlauwe B, Giller KE (2018) Sustainable intensification through rotations with grain legumes in sub-Saharan Africa: a review. Agric Ecosyst Environ 261:172-185. https://doi.org/10.1016/j.agee.2017.09.029

Giller KE, Andersson JA, Corbeels M, Kirkegaard J, Mortensen D, Erenstein O. and Vanlauwe B (2015) Beyond conservation agriculture. Front. Plant Sci 6:870. https://doi.org/10.3389/fpls.2015.00870

Giller KE, Witter E, Corbeels M, Tittonell P (2009) Conservation agriculture and smallholder farming in Africa: the heretics' view. Field Crop Res 114:23-34. https://doi.org/10.1016/j.fcr.2009.06.017

Grabowski PP, Kerr JM (2014) Resource constraints and partial adoption of conservation agriculture by hand-hoe farmers in Mozambique. Int J Agric Sustain 12:37-53. https://doi.org/10.1080/14735903.2013. 782703

Grassini P, Eskridge KM, Cassman KG (2013) Distinguishing between yield advances and yield plateaus in historical crop production trends. Nat Commun 4:1-11. https://doi.org/10.1038/ncomms3918

Hayashi K, Abdoulaye T, Gerard B, Bationo A (2008) Evaluation of application timing in fertilizer micro-dosing technology on millet production in Niger, West Africa. Nutr Cycl Agroecosyst 80:257265. https://doi.org/10.1007/s10705-007-9141-3

Hobbs PR, Sayre K, Gupta R (2008) The role of conservation agriculture in sustainable agriculture. Philoso Transac Royal Soc B: Biol Sci 363:543-555. https://doi.org/10.1098/rstb.2007.2169

Ibrahim A, Fatondji D (2020) Optimizing manure management for enhancing millet yields and resources use efficiency under rehabilitated plinthosols in the Sahel. J Arid Environ 181:104225. https://doi. org/10.1016/j.jaridenv.2020.104225

Ibrahim A, Abaidoo RC, Fatondji D, Opoku A (2015) Hill placement of manure and fertilizer micro-dosing improves yield and water use efficiency in the Sahelian low input millet-based cropping system. Field Crop Res 180:29-36. https://doi.org/10.1016/j.fcr.2015.04. 022

Ibrahim A, Abaidoo RC, Fatondji D, Opoku A (2016a) Fertilizer microdosing increases crop yield in the Sahelian low-input cropping system: a success with a shadow. Soil Sci Plant Nutr 62:277-288. https://doi.org/10.1080/00380768.2016.1194169

Ibrahim A, Abaidoo RC, Fatondji D, Opoku A (2016b) Determinants of fertilizer microdosing-induced yield increment of pearl millet on an acid sandy soil. Exp Agric 52:562-578. https://doi.org/10.1017/ S0014479715000241

IPCC (2014) Contribution of Working Groups I, II and III to the fifth assessment report of the Intergovernmental Panel on Climate Change (IPCC). In: Climate change 2014: synthesis report. IPCC, Geneva

Kaboré D, Reij C (2004) The emergence and spreading of an improved traditional soil and water conservation practice in Burkina Faso. International Food Policy Research Institute, Washington DC
Kafesu N, Chikowo R, Mazarura U, Gwenzi W, Snapp S, Zingore S (2018) Comparative fertilization effects on maize productivity under conservation and conventional tillage on sandy soils in a smallholder cropping system in Zimbabwe. Field Crop Res 218:106-114. https://doi.org/10.1016/j.fcr.2018.01.014

Kamanga BCG, Waddington SR, Whitbread AM et al (2014) Improving the efficiency of use of small amounts of nitrogen and phosphorus fertiliser on smallholder maize in central Malawi. Exp Agric 50: 229-249. https://doi.org/10.1017/S0014479713000513

Kaonga ML, Bayliss-Smith TP. (2009) Carbon pools in tree biomass and the soil in improved fallows in eastern Zambia. Agrofor Syst 76(1): $37-51$

Kebede Y, Baudron F, Bianchi F, Tittonell P (2018) Unpacking the pushpull system: assessing the contribution of companion crops along a gradient of landscape complexity. Agric Ecosyst Environ 268:115123. https://doi.org/10.1016/j.agee.2018.09.012

Kermah M, Franke AC, Ahiabor BDK et al (2019) Legume-maize rotation or relay? Options for ecological intensification of smallholder farms in the Guinea savanna of northern Ghana. Exp Agric 55:673691. https://doi.org/10.1017/S0014479718000273

Khan ZR, Hassanali A, Overholt W, Khamis TM, Hooper AM, Pickett JA, Wadhams LJ, Woodcock CM (2002) Control of witchweed Striga hermonthica by intercropping with Desmodium spp., and the mechanism defined as allelopathic. J Chem Ecol 28:18711885. https://doi.org/10.1023/A:1020525521180

Khan ZR, Pickett JA, Wadhams LJ, Hassanali A, Midega CAO (2006) Combined control of Striga hermonthica and stemborers by maizeDesmodium spp. intercrops. Crop Prot 25:989-995. https://doi.org/ 10.1016/j.cropro.2006.01.008

Khan ZR, Midega CA, Wanyama JM et al (2009) Integration of edible beans (Phaseolus vulgaris L.) into the push-pull technology developed for stemborer and Striga control in maize-based cropping systems. Crop Prot 28:997-1006. https://doi.org/10.1016/j.cropro. 2009.05.014

Khan ZR, Midega CAO, Pittchar JO, Murage AW, Birkett MA, Bruce TJA, Pickett JA (2014) Achieving food security for one million subSaharan African poor through push-pull innovation by 2020 . Philoso Transac Royal Soc B: Biol Sci 369:20120284. https://doi. org/10.1098/rstb.2012.0284

Kihara J, Bolo P, Kinyua M, Nyawira SS, Sommer R (2020) Soil health and ecosystem services: lessons from sub-Sahara Africa (SSA). Geoderma 370:114342. https://doi.org/10.1016/j.geoderma.2020. 114342

Kim D-G (2012) Estimation of net gain of soil carbon in a nitrogen-fixing tree and crop intercropping system in sub-Saharan Africa: results from re-examining a study. Agrofor Syst 86:175-184. https://doi. org/10.1007/s10457-011-9477-1

Kim D-G, Kirschbaum MU, Beedy TL (2016) Carbon sequestration and net emissions of $\mathrm{CH} 4$ and $\mathrm{N} 2 \mathrm{O}$ under agroforestry: synthesizing available data and suggestions for future studies. Agric Ecosyst Environ 226:65-78. https://doi.org/10.1016/j.agee.2016.04.011

Kimaro A.A, Isaac ME, Chamshama SAO (2011) Carbon Pools in Tree Biomass and Soils Under Rotational Woodlot Systems in Eastern Tanzania. In: Kumar B., Nair P. (eds) Carbon Sequestration Potential of Agroforestry Systems. Advances in Agroforestry, vol 8. Springer, Dordrecht. https://doi.org/10.1007/978-94-007-16308_7.

Kimaro AA, Timmer VR, Chamshama SAO, Ngaga YN, Kimaro DA (2009) Competition between maize and pigeonpea in semi-arid Tanzania: effect on yields and nutrition of crops. Agric Ecosyst Environ 134:115-125. https://doi.org/10.1016/j.agee.2009.06.002

Kinama J, Stigter C, Ong C et al (2007) Contour hedgerows and grass strips in erosion and runoff control on sloping land in semi-arid Kenya. Arid Land Res Manag 21:1-19. https://doi.org/10.1080/ 15324980601074545 
Kiptot E, Hebinck P, Franzel S, Richards P (2007) Adopters, testers or pseudo-adopters? Dynamics of the use of improved tree fallows by farmers in western Kenya. Agric Syst 94:509-519

Kiwia A, Kimani D, Harawa R, Jama B, Sileshi GW (2019) Sustainable intensification with cereal-legume intercropping in Eastern and Southern Africa. Sustainability 11:2891. https://doi.org/10.3390/ su11102891

Komarek AM, Kwon H, Haile B, Thierfelder C, Mutenje MJ, Azzarri C (2019) From plot to scale: ex-ante assessment of conservation agriculture in Zambia. Agric Syst 173:504-518. https://doi.org/10.1016/ j.agsy.2019.04.001

Kuria AW, Barrios E, Pagella T, Muthuri CW, Mukuralinda A, Sinclair FL (2019) Farmers' knowledge of soil quality indicators along a land degradation gradient in Rwanda. Geoderma Reg 16:e0199. https://doi.org/10.1016/j.geodrs.2018.e00199

Kuyah S, Öborn I, Jonsson M, Dahlin AS, Barrios E, Muthuri C, Malmer A, Nyaga J, Magaju C, Namirembe S, Nyberg Y, Sinclair FL (2016) Trees in agricultural landscapes enhance provision of ecosystem services in Sub-Saharan Africa. Int J Biodiver Sci Ecosyst Serv Manag 12:255-273. https://doi.org/10.1080/21513732.2016. 1214178

Kuyah S, Whitney CW, Jonsson M, Sileshi GW, Öborn I, Muthuri CW, Luedeling E (2019) Agroforestry delivers a win-win solution for ecosystem services in sub-Saharan Africa. A meta-analysis. Agron Sustain Dev 39:47. https://doi.org/10.1007/s13593-019-0589-8

Kuyah S, Sileshi GW, Luedeling E et al (2020) Potential of agroforestry to enhance livelihood security in Africa. In: In: Agroforestry for degraded landscapes. Springer, Berlin, pp 135-167

Lee N, Thierfelder C (2017) Weed control under conservation agriculture in dryland smallholder farming systems of southern Africa. A review. Agron Sustain Dev 37:48. https://doi.org/10.1007/s13593017-0453-7

Liben FM, Tadesse B, Tola YT, Wortmann CS, Kim HK, Mupangwa W (2018) Conservation agriculture effects on crop productivity and soil properties in Ethiopia. Agron J 110:758-767

Lipper L, Thornton P, Campbell BM, Baedeker T, Braimoh A, Bwalya M, Caron P, Cattaneo A, Garrity D, Henry K, Hottle R, Jackson L, Jarvis A, Kossam F, Mann W, McCarthy N, Meybeck A, Neufeldt H, Remington T, Sen PT, Sessa R, Shula R, Tibu A, Torquebiau EF (2014) Climate-smart agriculture for food security. Nat Clim Chang 4:1068-1072. https://doi.org/10.1038/nclimate2437

Madembo C, Mhlanga B, Thierfelder C (2020) Productivity or stability? Exploring maize-legume intercropping strategies for smallholder conservation agriculture farmers in Zimbabwe. Agric Syst 185: 102921. https://doi.org/10.1016/j.agsy.2020.102921

Magombeyi MS, Taigbenu AE, Barron J (2018) Effectiveness of agricultural water management technologies on rainfed cereals crop yield and runoff in semi-arid catchment: a meta-analysis. Int J Agric Sustain 16:418-441. https://doi.org/10.1080/14735903.2018. 1523828

Malley ZJU, Kayombo B, Willcocks TJ, Mtakwa PW (2004) Ngoro: an indigenous, sustainable and profitable soil, water and nutrient conservation system in Tanzania for sloping land. Soil Tillage Res 77: 47-58. https://doi.org/10.1016/j.still.2003.10.003

Mashavakure N, Mashingaidze AB, Musundire R et al (2018) Short-term impacts of tillage and fertilizer treatments on soil and root borne nematodes and maize yield in a fine textured cambisol. J Nematol 50:329-342. https://doi.org/10.21307/jofnem-2018-033

Meijer SS, Catacutan D, Ajayi OC, Sileshi GW, Nieuwenhuis M (2015) The role of knowledge, attitudes and perceptions in the uptake of agricultural and agroforestry innovations among smallholder farmers in sub-Saharan Africa. Int J Agric Sustain 13:40-54. https://doi.org/10.1080/14735903.2014.912493

Micheni AN, Kanampiu F, Kitonyo O et al (2016) On-farm experimentation on conservation agriculture in maize-legume based cropping systems in Kenya: water use efficiency and economic impacts. Exp Agric 52:51-68. https://doi.org/10.1017/S0014479714000556

Midega CAO, Bruce TJA, Pickett JA, Pittchar JO, Murage A, Khan ZR (2015) Climate-adapted companion cropping increases agricultural productivity in East Africa. Field Crop Res 180:118-125. https:// doi.org/10.1016/j.fcr.2015.05.022

Midega CA, Wasonga CJ, Hooper AM et al (2017) Drought-tolerant Desmodium species effectively suppress parasitic striga weed and improve cereal grain yields in western Kenya. Crop Prot 98:94-101. https://doi.org/10.1016/j.cropro.2017.03.018

Midega CAO, Pittchar JO, Pickett JA, Hailu GW, Khan ZR (2018) A climate-adapted push-pull system effectively controls fall armyworm, Spodoptera frugiperda (J E Smith), in maize in East Africa. Crop Prot 105:10-15. https://doi.org/10.1016/j.cropro.2017.11.003

Muchai SWK, Ngetich FK, Baaru M, Mucheru-Muna MW (2020) Adoption and utilisation of Zai pits for improved farm productivity in drier upper eastern Kenya. J Agric Rural Dev Trop Subtrop 121: 13-22. https://doi.org/10.17170/kobra-202002281030

Muchane MN, Sileshi GW, Gripenberg S, Jonsson M, Pumariño L, Barrios E (2020) Agroforestry boosts soil health in the humid and sub-humid tropics: a meta-analysis. Agric Ecosyst Environ 295: 106899. https://doi.org/10.1016/j.agee.2020.106899

Mupangwa W, Nyagumbo I, Mutsamba E (2016) Effect of different mulching materials on maize growth and yield in conservation agriculture systems of sub-humid Zimbabwe. AIMS Agricult Food 1: 239-253. https://doi.org/10.3934/agrfood.2016.2.239

Mupangwa W, Nyagumbo I, Mutsamba E, Mhlanga B, Mataruse J (2018) Maize responses to reduced tillage, different plant residue mulch and nitrogen fertiliser on granitic sandy soils of Zimbabwe. S Afri J Plant Soil 35:367-376. https://doi.org/10.1080/02571862. 2018.1438673

Mupangwa W, Thierfelder C, Cheesman S, Nyagumbo I, Muoni T, Mhlanga B, Mwila M, Sida TS, Ngwira A (2019) Effects of maize residue and mineral nitrogen applications on maize yield in conservation-agriculture-based cropping systems of Southern Africa. Renew Agricult Food Syst 35:322-335. https://doi.org/10. 1017/S174217051900005X

Mupangwa W, Nyagumbo I, Liben F, Chipindu L, Craufurd P, Mkuhlani S (2021) Maize yields from rotation and intercropping systems with different legumes under conservation agriculture in contrasting agro-ecologies. Agric Ecosyst Environ 306:107170

Murage AW, Midega CAO, Pittchar JO, Pickett JA, Khan ZR (2015) Determinants of adoption of climate-smart push-pull technology for enhanced food security through integrated pest management in eastern Africa. Food Secur 7:709-724

Musumba M, Grabowski P, Palm C, Snapp SS (2017) Guide for the sustainable intensification assessment framework. Feed the Future

Mutegi JK, Mugendi DN, Verchot LV, Kung'u JB (2008) Combining Napier grass with leguminous shrubs in contour hedgerows controls soil erosion without competing with crops. Agrofor Syst 74:37-49. https://doi.org/10.1007/s10457-008-9152-3

Mutuku EA, Roobroeck D, Vanlauwe B, Boeckx P, Cornelis WM (2020) Maize production under combined conservation agriculture and integrated soil fertility management in the sub-humid and semi-arid regions of Kenya. Field Crop Res 254:e107833. https://doi.org/10. 1016/j.fcr.2020.107833

Mwinuka L, Mutabazi KD, Graef F, Sieber S, Makindara J, Kimaro A, Uckert G (2017) Simulated willingness of farmers to adopt fertilizer micro-dosing and rainwater harvesting technologies in semi-arid and sub-humid farming systems in Tanzania. Food Secur 9:12371253

Myaka FM, Sakala WD, Adu-Gyamfi JJ, Kamalongo D, Ngwira A, Odgaard R, Nielsen NE, Høgh-Jensen H (2006) Yields and accumulations of $\mathrm{N}$ and $\mathrm{P}$ in farmer-managed intercrops of maizepigeonpea in semi-arid Africa. Plant Soil 285:207-220. https://doi. org/10.1007/s11104-006-9006-6 
Namatsheve T, Cardinael R, Corbeels M, Chikowo R (2020) Productivity and biological N2-fixation in cereal-cowpea intercropping systems in sub-Saharan Africa. A review. Agron Sustain Dev 40:30. https:// doi.org/10.1007/s13593-020-00629-0

Nassary EK, Baijukya F, Ndakidemi PA (2020a) Assessing the productivity of common bean in intercrop with maize across agroecological zones of smallholder farms in the Northern highlands of Tanzania. Agricult (Switzerland) 10:117. https://doi.org/10.3390/ agriculture10040117

Nassary EK, Baijukya F, Ndakidemi PA (2020b) Productivity of intercropping with maize and common bean over five cropping seasons on smallholder farms of Tanzania. Eur J Agron 113:125964. https://doi.org/10.1016/j.eja.2019.125964

Ncube B, Dimes JP, Twomlow SJ, Mupangwa W, Giller KE (2007) Raising the productivity of smallholder farms under semi-arid conditions by use of small doses of manure and nitrogen: a case of participatory research. Nutr Cycl Agroecosyst 77:53-67. https:// doi.org/10.1007/s10705-006-9045-7

Ndayisaba PC, Kuyah S, Midega CAO, Mwangi PN, Khan ZR (2020) Push-pull technology improves maize grain yield and total aboveground biomass in maize-based systems in Western Kenya. Field Crop Res 256:107911. https://doi.org/10.1016/j.fcr.2020.107911

Nkonya E, Mirzabaev A, Von Braun J (2016) Economics of land degradation and improvement: a global assessment for sustainable development. Springer International Publishing Cham, Switzerland

Nkurunziza L, Chirinda N, Lana M, Sommer R, Karanja S, Rao I, Romero Sanchez MA, Quintero M, Kuyah S, Lewu F, Joel A, Nyamadzawo G, Smucker A (2019) The potential benefits and trade-offs of using sub-surface water retention technology on coarse-textured soils: impacts of water and nutrient saving on maize production and soil carbon sequestration. Front Sustain Food Syst 3: 71. https://doi.org/10.3389/fsufs.2019.00071

Nourou AIM, Saidou AK, Arifa W et al (2020) Intensification of pearl millet production in Niger through mechanized sowing and weeding, seed priming, seed treatment, and microdosing. Agronomy 10, 12. https://doi.org/10.3390/agronomy10050629

Nyagumbo I, Munamati M, Mutsamba EF, Thierfelder C, Cumbane A, Dias D (2015) The effects of tillage, mulching and termite control strategies on termite activity and maize yield under conservation agriculture in Mozambique. Crop Prot 78:54-62. https://doi.org/ 10.1016/j.cropro.2015.08.017

Nyagumbo I, Mkuhlani S, Pisa C, Kamalongo D, Dias D, Mekuria M (2016) Maize yield effects of conservation agriculture based maizelegume cropping systems in contrasting agro-ecologies of Malawi and Mozambique. Nutr Cycl Agroecosyst 105:275-290. https://doi. org/10.1007/s10705-015-9733-2

Nyagumbo I, Mupangwa W, Chipindu L, Rusinamhodzi L, Craufurd P (2020) A regional synthesis of seven-year maize yield responses to conservation agriculture technologies in Eastern and Southern Africa. Agric Ecosyst Environ 295:106898. https://doi.org/10. 1016/j.agee.2020.106898

Nziguheba G, Zingore S, Kihara J, Merckx R, Njoroge S, Otinga A, Vandamme E, Vanlauwe B (2016) Phosphorus in smallholder farming systems of sub-Saharan Africa: implications for agricultural intensification. Nutr Cycl Agroecosyst 104:321-340. https://doi.org/ 10.1007/s10705-015-9729-y

Odeny DA (2007) The potential of pigeonpea (Cajanus cajan (L.) Millsp.) in Africa. Nat Res Forum 31:297-305. https://doi.org/10. 1111/j.1477-8947.2007.00157.x

Ojiem JO, Franke AC, Vanlauwe B, de Ridder N, Giller KE (2014) Benefits of legume-maize rotations: assessing the impact of diversity on the productivity of smallholders in Western Kenya. Field Crop Res 168:75-85. https://doi.org/10.1016/j.fcr.2014.08.004

Okebalama CB, Safo EY, Yeboah E, Abaidoo RC, Logah V (2016) Fertilizer microdosing in the humid forest zone of Ghana: an efficient strategy for increasing maize yield and income in smallholder farming. Soil Sci Soc Am J 80:1254-1261. https://doi.org/10.2136/ sssaj2016.03.0065

Okorio J, Maghembe JA (1994) The growth and yield of Acacia albida intercropped with maize (Zea mays) and beans (Phaseolus vulgaris) at Morogoro, Forest Ecology and Management 64(2-3):183-90

Ouedraogo Y, Taonda J-BS, Sermé I, Tychon B, Bielders CL (2020) Factors driving cereal response to fertilizer microdosing in subSaharan Africa: a meta-analysis. Agron J 112:2418-2431. https:// doi.org/10.1002/agj2.20229

Partey S, Zougmoré R, Ouédraogo M, Thevathasan N (2017) Why promote improved fallows as a climate-smart agroforestry technology in sub-Saharan Africa? Sustainability 9:1887. https://doi.org/10. 3390/su9111887

Pittelkow CM, Liang X, Linquist BA, van Groenigen KJ, Lee J, Lundy ME, van Gestel N, Six J, Venterea RT, van Kessel C (2015a) Productivity limits and potentials of the principles of conservation agriculture. Nature 517:365-368. https://doi.org/10.1038/ nature 13809

Pittelkow CM, Linquist BA, Lundy ME, Liang X, van Groenigen KJ, Lee J, van Gestel N, Six J, Venterea RT, van Kessel C (2015b) When does no-till yield more? A global meta-analysis. Field Crop Res 183: 156-168. https://doi.org/10.1016/j.fcr.2015.07.020

Pretty JN (1997) The sustainable intensification of agriculture. Nat Res Forum 21:247-256. https://doi.org/10.1111/j.1477-8947.1997. tb00699.x

Pretty J, Toulmin C, Williams S (2011) Sustainable intensification in African agriculture. Int J Agric Sustain 9:5-24. https://oi.org/10. 3763/ijas.2010.0583

Pugesgaard S, Petersen SO, Chirinda N, Olesen JE (2017) Crop residues as driver for $\mathrm{N}_{2} \mathrm{O}$ emissions from a sandy loam soil. Agric For Meteorol 233:45-54. https://doi.org/10.1016/j.agrformet.2016.11. 007

Pumariño L, Sileshi GW, Gripenberg S, Kaartinen R, Barrios E, Muchane MN, Midega C, Jonsson M (2015) Effects of agroforestry on pest, disease and weed control: a meta-analysis. Basic Appl Ecol 16:573582. https://doi.org/10.1016/j.baae.2015.08.006

Rahn E, Liebig T, Ghazoul J, van Asten P, Läderach P, Vaast P, Sarmiento A, Garcia C, Jassogne L (2018) Opportunities for sustainable intensification of coffee agro-ecosystems along an altitudinal gradient on Mt. Elgon, Uganda. Agriculture. Ecosyst Environ 263:31-40. https://doi.org/10.1016/j.agee.2018.04.019

Rao MR, Mathuva MN (2000) Legumes for improving maize yields and income in semi-arid Kenya. Agric Ecosyst Environ 78:123-137. https://doi.org/10.1016/S0167-8809(99)00125-5

Ray DK, Mueller ND, West PC, Foley JA (2013) Yield trends are insufficient to double global crop production by 2050. PLoS One 8: e66428. https://doi.org/10.1371/journal.pone.0066428

Rogé P, Snapp S, Kakwera MN, Mungai L, Jambo I, Peter B (2016) Ratooning and perennial staple crops in Malawi. A review. Agron Sustain Dev 36:50. https://doi.org/10.1007/s13593-016-0384-8

Roose E, Kabore V, Guenat C (1999) Zaï practice: a West African traditional rehabilitation system for semiarid degraded lands, a case study in Burkina Faso. Arid Soil Res Rehabil 13:343-355. https://doi.org/ 10.1080/089030699263230

Rosenstock TS, Mpanda M, Rioux J, Aynekulu E, Kimaro AA, Neufeldt H, Shepherd KD, Luedeling E (2014) Targeting conservation agriculture in the context of livelihoods and landscapes. Agric Ecosyst Environ 187:47-51. https://doi.org/10.1016/j.agee.2013.11.011

Rusinamhodzi L, Corbeels M, van Wijk MT, Rufino MC, Nyamangara J, Giller KE (2011) A meta-analysis of long-term effects of conservation agriculture on maize grain yield under rain-fed conditions. Agron Sustain Dev 31:657-673. https://doi.org/10.1007/s13593011-0040-2

Rusinamhodzi L, Corbeels M, Nyamangara J, Giller KE (2012) Maizegrain legume intercropping is an attractive option for ecological intensification that reduces climatic risk for smallholder farmers in 
central Mozambique. Field Crop Res 136:12-22. https://doi.org/10. 1016/j.fcr.2012.07.014

Rusinamhodzi L, Makumbi D, Njeru JM, Kanampiu F (2020) Performance of elite maize genotypes under selected sustainable intensification options in Kenya. Field Crop Res 249:107738. https://doi.org/10.1016/j.fcr.2020.107738

Saidia PS, Asch F, Kimaro AA, Germer J, Kahimba FC, Graef F, Semoka JMR, Rweyemamu CL (2019) Soil moisture management and fertilizer micro-dosing on yield and land utilization efficiency of intercropping maize-pigeon-pea in sub humid Tanzania. Agric Water Manag 223:105712. https://doi.org/10.1016/j.agwat.2019.105712

Sida TS, Baudron F, Hadgu K, Derero A, Giller KE (2018) Crop vs. tree: can agronomic management reduce trade-offs in tree-crop interactions? Agriculture. Ecosyst Environ 260:36-46. https://doi.org/10. 1016/j.agee.2018.03.011

Sida TS, Baudron F, Ndoli A, Tirfessa D, Giller KE (2020) Should fertilizer recommendations be adapted to parkland agroforestry systems? Case studies from Ethiopia and Rwanda. Plant Soil 453: 173-188. https://doi.org/10.1007/s11104-019-04271-y

Sileshi G, Akinnifesi FK, Ajayi OC, Place F (2008) Meta-analysis of maize yield response to woody and herbaceous legumes in subSaharan Africa. Plant Soil 307:1-19. https://doi.org/10.1007/ s11104-008-9547-y

Sileshi GW, Mafongoya PL, Akinnifesi FK et al (2014) Agroforestry: fertilizer trees. Encyclop Agricult Food Syst 1:222-234. https://doi. org/10.1016/B978-0-444-52512-3.00022-X

Sinclair FL (1999) A general classification of agroforestry practice. Agrofor Syst 46(2):161-180. https://doi.org/10.1023/A: 1006278928088

Smith A, Snapp S, Dimes J, Gwenambira C, Chikowo R (2016) Doubledup legume rotations improve soil fertility and maintain productivity under variable conditions in maize-based cropping systems in Malawi. Agric Syst 145:139-149. https://doi.org/10.1016/j.agsy. 2016.03.008

Smith A, Snapp S, Chikowo R, Thorne P, Bekunda M, Glover J (2017) Measuring sustainable intensification in smallholder agroecosystems: a review. Global Food Secur 12:127-138. https:// doi.org/10.1016/j.gfs.2016.11.002

Snapp S, Kanyama-Phiri G, Kamanga B, Gilbert R, Wellard K (2002a) Farmer and researcher partnerships in Malawi: developing soil fertility technologies for the near-term and far-term. Exp Agric 38:411431. https://doi.org/10.1017/S0014479702000443

Snapp SS, Rohrbach DD, Simtowe F, Freeman HA (2002b) Sustainable soil management options for Malawi: can smallholder farmers grow more legumes? Agric Ecosyst Environ 91:159-174. https://doi.org/ 10.1016/S0167-8809(01)00238-9

Snapp SS, Blackie MJ, Gilbert RA, Bezner-Kerr R, Kanyama-Phiri GY (2010) Biodiversity can support a greener revolution in Africa. Proc Natl Acad Sci 107:20840-20845. https://doi.org/10.1073/pnas. 1007199107

Snapp SS, Grabowski P, Chikowo R, Smith A, Anders E, Sirrine D, Chimonyo V, Bekunda M (2018a) Maize yield and profitability tradeoffs with social, human and environmental performance: is sustainable intensification feasible? Agric Syst 162:77-88. https:// doi.org/10.1016/j.agsy.2018.01.012

Snapp SS, Rahmanian M, Batello C (2018b) Pulse crops for sustainable farms in sub-Saharan Africa. Food and Agriculture Organization of the United Nations (FAO), Rome

Tabo R, Bationo A, Gerard B et al (2007) Improving cereal productivity and farmers' income using a strategic application of fertilizers in West Africa. In: Bationo A, Kihara J, Kimetu J (eds) Advances in integrated soil fertility management in sub-Saharan Africa: challenges and opportunities. Springer, Dordrecht, pp 201-208

TerAvest D, Carpenter-Boggs L, Thierfelder C, Reganold JP (2015) Crop production and soil water management in conservation agriculture, no-till, and conventional tillage systems in Malawi. Agric Ecosyst Environ 212:285-296. https://doi.org/10.1016/j.agee.2015.07.011

Thierfelder C, Matemba-Mutasa R, Rusinamhodzi L (2015) Yield response of maize (Zea mays L.) to conservation agriculture cropping system in Southern Africa. Soil Tillage Res 146:230-242. https:// doi.org/10.1016/j.still.2014.10.015

Thierfelder C, Matemba-Mutasa R, Bunderson WT, Mutenje M, Nyagumbo I, Mupangwa W (2016) Evaluating manual conservation agriculture systems in southern Africa. Agric Ecosyst Environ 222: 112-124. https://doi.org/10.1016/j.agee.2016.02.009

Thierfelder C, Chivenge P, Mupangwa W, Rosenstock TS, Lamanna C, Eyre JX (2017) How climate-smart is conservation agriculture (CA)? - its potential to deliver on adaptation, mitigation and productivity on smallholder farms in southern Africa. Food Secur 9: 537-560. https://doi.org/10.1007/s12571-017-0665-3

Tonitto C, Ricker-Gilbert JE (2016) Nutrient management in African sorghum cropping systems: applying meta-analysis to assess yield and profitability. Agron Sustain Dev 36:10. https://doi.org/10.1007/ s13593-015-0336-8

Tongwane M, Mdlambuzi T, Moeletsi M, Tsubo M, Mliswa V, Grootboom L (2016) Greenhouse gas emissions from different crop production and management practices in South Africa. Environ Dev 19:23-35. https://doi.org/10.1016/j.envdev.2016.06.004

Tovihoudji PG, Akponikpè PI, Agbossou EK et al (2017) Fertilizer microdosing enhances maize yields but may exacerbate nutrient mining in maize cropping systems in northern Benin. Field Crop Res 213:130-142. https://doi.org/10.1016/j.fcr.2017.08.003

Tovihoudji PG, Akponikpè PBI, Agbossou EK, Bielders CL (2019) Variability in maize yield and profitability following hillplacement of reduced mineral fertilizer and manure rates under smallholder farm conditions in northern Benin. Field Crop Res 230:139-150. https://doi.org/10.1016/j.fcr.2018.10.018

Twomlow S, Rohrbach D, Dimes J, Rusike J, Mupangwa W, Ncube B, Hove L, Moyo M, Mashingaidze N, Mahposa P (2010) Microdosing as a pathway to Africa's Green Revolution: evidence from broad-scale on-farm trials. Nutr Cycl Agroecosyst 8:3-15. https:// doi.org/10.1007/s10705-008-9200-4

United Nations (2017) World population prospects: the 2017 revision. Department of Economic and Social Affairs. United Nations, New York

Valentini R, Arneth A, Bombelli A, Castaldi S, Cazzolla Gatti R, Chevallier F, Ciais P, Grieco E, Hartmann J, Henry M, Houghton RA, Jung M, Kutsch WL, Malhi Y, Mayorga E, Merbold L, MurrayTortarolo G, Papale D, Peylin P, Poulter B, Raymond PA, Santini M, Sitch S, Vaglio Laurin G, van der Werf GR, Williams CA, Scholes RJ (2013) The full greenhouse gases budget of Africa: synthesis, uncertainties and vulnerabilities. Biogeosci Discuss 10:84138407. https://doi.org/10.5194/bg-11-381-2014

van Vugt D, Franke AC, Giller KE (2018) Understanding variability in the benefits of N2-fixation in soybean-maize rotations on smallholder farmers' fields in Malawi. Agric Ecosyst Environ 261:241-250. https://doi.org/10.1016/j.agee.2017.05.008

Vandamme E, Ahouanton K, Mwakasege L, Mujuni S, Mujawamariya G, Kamanda J, Senthilkumar K, Saito K (2018) Phosphorus microdosing as an entry point to sustainable intensification of rice systems in sub-Saharan Africa. Field Crop Res 222:39-49. https://doi.org/ 10.1016/j.fcr.2018.02.016

Vanlauwe B, Coyne D, Gockowski J, Hauser S, Huising J, Masso C, Nziguheba G, Schut M, van Asten P (2014) Sustainable intensification and the African smallholder farmer. Curr Opin Environ Sustain 8:15-22. https://doi.org/10.1016/j.cosust.2014.06.001

Waddington SR, Mekuria M, Siziba S, Karigwindi J (2007) Long-term yield sustainability and financial returns from grain legume-maize intercrops on a sandy soil in sub-humid north central Zimbabwe. Exp Agric 43:489 503. https://doi.org/10.1017/S0014479707005303 
Weltin M, Zasada I, Plogmann J-M, Trau FN, Piorr A (2018) Data on the scope of the literature on sustainable intensification 1997-2016: bibliography, geography and practical approaches. Data brief 19: $1658-1660$

Wolka K, Mulder J, Biazin B (2018) Effects of soil and water conservation techniques on crop yield, runoff and soil loss in Sub-Saharan Africa: a review. Agric Water Manag 207:67-79. https://doi.org/10. 1016/j.agwat.2018.05.016

Yimam AY, Assefa TT, Adane NF, Tilahun SA, Jha MK, Reyes MR (2020) Experimental evaluation for the impacts of conservation agriculture with drip irrigation on crop coefficient and soil properties in the Sub-Humid Ethiopian Highlands. Water (Switzerland) 12:947. https://doi.org/10.3390/W12040947
Zomer RJ, Trabucco A, Coe R, Place F, Van Noordwijk M, Xu JC (2014) Trees on farms: an update and reanalysis of agroforestry's global extent and socio-ecological characteristics. Working Paper 179. Bogor, Indonesia

Zougmoré R, Jalloh A, Tioro A (2014) Climate-smart soil water and nutrient management options in semiarid West Africa: a review of evidence and analysis of stone bunds and zaï techniques. Agricult Food Secur 3:16. https://doi.org/10.1186/2048-7010-3-16

Publisher's note Springer Nature remains neutral with regard to jurisdictional claims in published maps and institutional affiliations. 